University of Rhode Island

DigitalCommons@URI

Open Access Master's Theses

1991

\title{
Overcapacity at Port Container Facilities: Planning Techniques and Policy Concerns
}

\author{
Eric T. Anderson \\ University of Rhode Island
}

Follow this and additional works at: https://digitalcommons.uri.edu/theses

\section{Recommended Citation}

Anderson, Eric T., "Overcapacity at Port Container Facilities: Planning Techniques and Policy Concerns" (1991). Open Access Master's Theses. Paper 1169.

https://digitalcommons.uri.edu/theses/1169

This Thesis is brought to you for free and open access by DigitalCommons@URI. It has been accepted for inclusion in Open Access Master's Theses by an authorized administrator of DigitalCommons@URI. For more information, please contact digitalcommons-group@uri.edu. 
OVERCAPACITY AT PORT CONTAINER FACILITIES: PLANNING TECHNIQUES AND POLICY CONCERNS

BY

ERIC T. ANDERSON

A THESIS SUBMITTED IN PARTIAL FULFILLMENT OF THE REQUIREMENTS FOR THE DEGREE OF MASTER OF ARTS

IN

MARINE AFFAIRS

UNIVERSITY OF RHODE ISLAND 


\title{
MASTER OF ARTS THESIS
}

\section{OF}

\author{
ERIC T. ANDERSON
}

\section{APPROVED:}

Thesis Committee

Major Professor

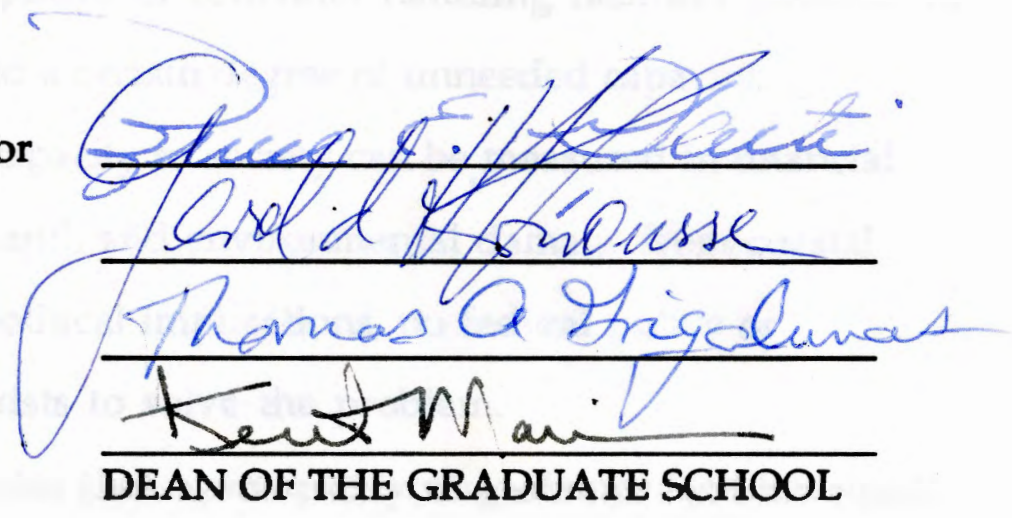




\section{ABSTRACT}

Containerization as a means of cargo transport represents the most progressive technological advance in shipping today. The efficiency that containerization presents to shippers has made it the preferred means of cargo transport by sea and land. As containerization continues to grow throughout the world, semi-autonomous public ports in the United States compete for larger shares of high valued cargo. Competition among ports has led to the extensive development of container handling facilities throughout the United States and created a certain degree of unneeded capacity.

The cost of this overcapacity to society can be measured in financial waste, opportunity cost of land, and environmental damage from coastal development. Despite its political implications, no federal policy or management mechanism exists to solve the problem.

This thesis demonstrates that overcapacity at container facilities exists and demands political attention as a public welfare issue. It is suggested that capacity analysis, if utilized by ports, can serve as a mechanism to prevent and correct the social inefficiencies of overcapacity from port competition. By utilizing a capacity monitoring and assessment tool similar to the method used in this thesis, government permit decision-makers and ports can produce more information to better make port development decisions. On a broad level, available capacity information can improve U.S. port facility development project planning.

This document quantitatively demonstrates the extent of container terminal excess among large ports (100,000 + TEUs annually) along the U.S. 
mid-Atlantic port range and presents evidence of a continuing overcapacity problem. Evidence supports the hypothesis that significant overcapacity resulting in social costs does indeed exist and requires political attention as a societal issue. 


\section{ACKNOWLEDGEMENTS}

I wish to thank my advisor, Professor Bruce E. Marti, for his continuing support and concern during the writing of this thesis. Much thanks to Thomas Brillat and Thomas Dowd for their help and insight. Also, a special thanks to Rexford Sherman of the American Association of Port Authorities, Todd Coyle of the Port of Norfolk and the ports of Baltimore, Charleston, Savannah and Jacksonville. In particular, I wish to thank my father for his editing expertise and guidance. 


\section{TABLE OF CONTENTS}

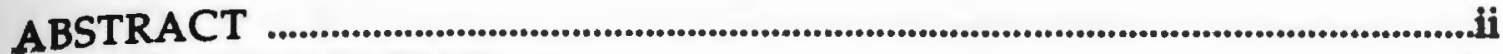

ACKNOWLEDGEMENTS..............................................................................................iv

TABLE OF CONTENTS ................................................................................................v

LIST OF TABLES ...................................................................................................vii

LIST OF FIGURES ............................................................................................................viii

CHAPTER ONE: PROBLEMS AND POLICY PERSPECTIVES.................................1

Hypothesis ............................................................................................................................7

Justification of Study .............................................................................................8

Overcapacity of Port Container Facilities......................................................10

Problems Defining Excess Port Capacity......................................................13

Public Port Entities Managed as Private Corporations................................14

Efficiency: The Conflict Between Business Decisions and

Public Interests..................................................................................................15

Federal Port Policy and Overcapacity of Container

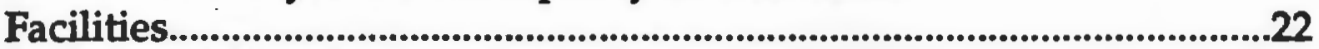

The Federal Role in Port Development......................................................24

Federal Jurisdiction and the Regulation of Port land Use........................26

State/Regional Policies and the Management of

Overcapacity....................................................................................................31

Summary ........................................................................................................................34

CHAPTER TWO: CONTAINERIZATION AND PORT DEVELOPMENT .....35

Containerization ............................................................................................35

Container Importance..................................................................................................39

Location Quotient .......................................................................................................41

Competition Among Container Facilities.......................................................46

CHAPTER THREE: CAPACITY ANALYSIS AND PRODUCTIVITY.................51

Measuring Container Productivity and Capacity........................................52

Productivity Factors Which Affect Container Facility

Operations................................................................................................................53

Method ...........................................................................................................56

Berth capacity .................................................................................................57

Yard capacity ..................................................................................................59

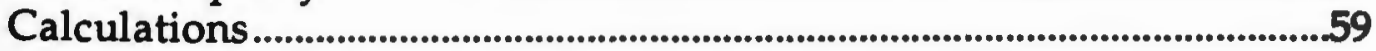

Average berth requirement .....................................................................60

Determining the number of model ship lines per port ....................60

Determining total berth requirement ……………………......................60

Determining yard requirement ...................................................................61 
Highest attainable berth productivity

.61

The Port of Baltimore (Dundalk Marine Terminal) .................................66

The Port of Norfolk ...................................................................................................67

The Port of Charleston (North Charleston Terminal)...............................68

The Port of Charleston (Wando Terminal) ...................................................71

The Port of Savannah (Containerport) ............................................................74

The Port of Jacksonville (Talleyrand and Blount Island

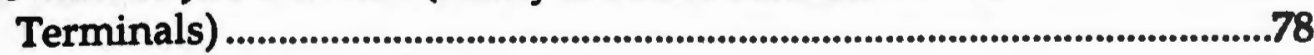

Other Ports .............................................................................................................82

CHAPTER FOUR: CONCLUSIONS ....................................................................87

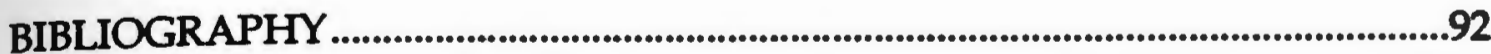




\section{LIST OF TABLES}

PAGE

TABLE 1: FACILITY SPECIFICATIONS …...............................................................9

TABLE 2: SUMMARY OF PORT EXPANSION PROJECTS..............................12

TABLE 3: NUMBER OF CONTAINERS ............................................................40

TABLE 4: CONTAINER TONNAGE v. TOTAL CARGO IN SHORT TONS.

TABLE 5: TEUS BY FACILITY

TABLE 6: BERTH CAPACITY CALCULATION....................................................58

TABLE 7: CAPACITY CALCULATION FOR THE DUNDALK MARINE TERMINAL (PORT OF BALTIMORE)

TABLE 8: CAPACITY CALCULATION FOR THE PORT OF NORFOLK....69

TABLE 9: CAPACITY CALCULATION FOR THE NORTH CHARLESON TERMINAL (PORT OF CHARLESTON)

TABLE 10: CAPACITY CALCULATION FOR THE WANDO TERMINAL (PORT OF CHARLESON).

TABLE 11: CAPACITY CALCULATION FOR CONTAINERPORT (PORT OF SAVANNAH). .76

TABLE 12: CAPACITY CALCULATION FOR BLOUNT ISLAND AND TALLEYRAND TERMINALS (PORT OF JACKSONVILLE)......80 


\section{LIST OF FIGURES}

\section{PAGE}

FIGURE 1: MID-ATLANTIC PORTS STUDIED. .2

FIGURE 2: BREAKDOWN OF REVENUE for CONTAINER CARGO AND BULK CARGO PER TON

FIGURE 3: PRELIMINARY REGIONAL CAPACITY CALCULATION v. ACTUAL REGIONAL CONTAINER THROUGHPUT

FIGURE 4: THEORETICAL COST CURVES REPRESENTING OPTIMAL LEVELS OF PRICE AND QUANTTTY FOR PORT DEVELOPMENT WHEN SOCIAL EXTERNAL COSTS ARE CONSIDERED

FIGURE 5: RECOMMENDED ORGANIZATIONAL PERMITTING STRUCTURE

FIGURE 6: RELATIVE CONTAINER IMPORTANCE

FIGURE 7: 1987-1989 MARKET-SHARE COMPARISON

FIGURE 8: DUNDALK MARINE TERMINAL EXCESS .66

FIGURE 9: NORFOLK TERMINAL EXCESS .70

FIGURE 10: NORTH CHARLESTON EXCESS. .73

FIGURE 11: PORT OF SAVANNAH (CONTAINERPORT) EXCESS. .77

FIGURE 12: PORT OF JACKSONVILLE EXCESS .81

FIGURE 13: TOTAL EXCESS THROUGHOUT STUDY RANGE .85

FIGURE 14: ACTUAL CARGO v. CAPACITY .86 


\section{CHAPTER ONE}

\section{PROBLEMS AND POLICY PERSPECTIVES}

Inter-port competition for containerized cargo in the United States Mid-Atlantic port range has led to extensive investment in and development of container handling facilities. From the ports of Baltimore to Jacksonville (See Figure 1), the development of duplicate facilities is a result of competition for container cargo. Thus, it is suggested that overcapacity exists within port container facilities throughout the range. The ports in this study were selected because of the known competition among them (Containerisation International, 1987). In addition, the Mid-Atlantic range exhibits characteristics which are representative of typical container ports throughout the nation. Therefore, the results of this study could have policy implications in other U.S. ports and port ranges.

Extreme overcapacity within a port and a range is symptomatic of inefficient port planning and coastal land use, and creates long-term environmental consequences associated with dredge and fill activity. As the mid-Atlantic container ports continue to develop and expand in order to accommodate a limited growth of cargo, the question of overcapacity must be addressed.

To a certain extent, excess capacity among U.S. ports is a natural condition of the system. It provides for peak trade periods and for specialized uses such as occasional military berthing. Excess capacity also allows cargo growth potential so a port can remain competitive (National Research 


\section{FIGURE 1}

\section{MID-ATLANTIC PORTS STUDIED}

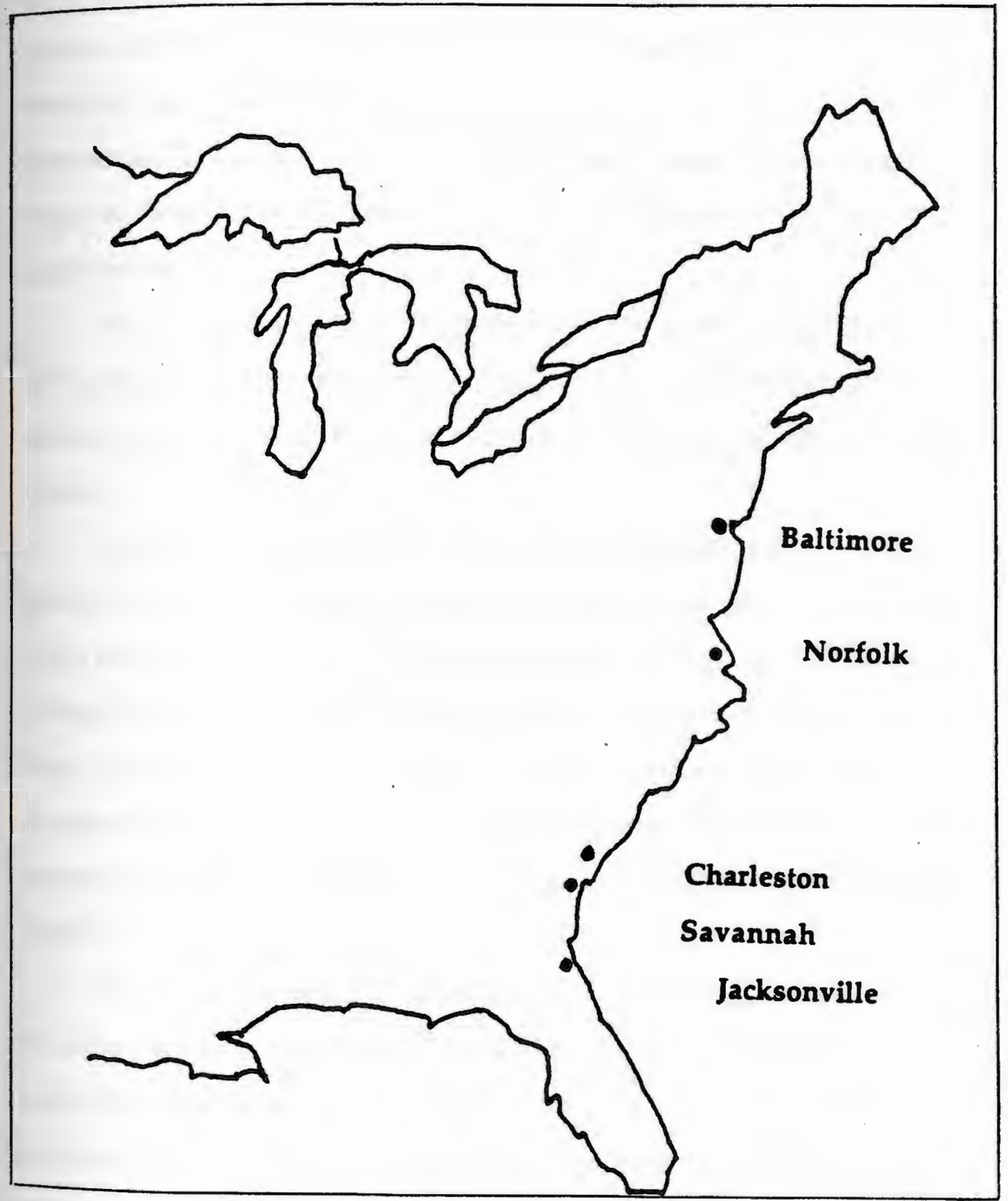


Council, 1976). Beyond this ancillary excess, however, a port may exhibit wasteful overcapacity in container facilities.

Many of the ports in the United States operate within a competitive structure, whereby individual ports are granted a charter from each state to operate and manage commerce upon its public coastal lands. Most ports, including all of those in this study, are managed by state-run port authorities.These entities operate autonomously from each other and with minimal federal control. Therefore, each port competes separately for container cargo.

As in any competitive free market system, ports attempt to gain certain advantages over their competitors. Accordingly, ports attempt to offer efficient, quality service that will expedite the loading and unloading of vessels.

Container cargo is usually comprised of general cargo or manufactured goods. The value of container cargo is high relative to other types of cargo (i.e. bulk) and is charged a higher price per ton for wharfage (cargo handling) and demurrage (removal form the port) relative to other cargo types (Figure 2). Ports generate more revenues when they can increase the amount of containerized cargo moving through their facilities (throughput). They attempt to attract more containerized cargo by improving and expanding port facilities.

Problems arise when a competing port provides at least as much container handling capability as its neighboring ports in order to maintain its cargo share and to secure a competitive position. The competition among ports is intense because their infrastructure (berths and storage yards) and superstructure (cargo handling equipment) do not vary significantly.

Competition among ports is achieved by increasing the capacity of facilities to 


\section{FIGURE 2}

\section{BREAKDOWN OF REVENUE for CONTAINER CARGO AND BULK CARGO PER TON \\ CONTAINER CARGO \\ PER TON $\$ 76.30$}

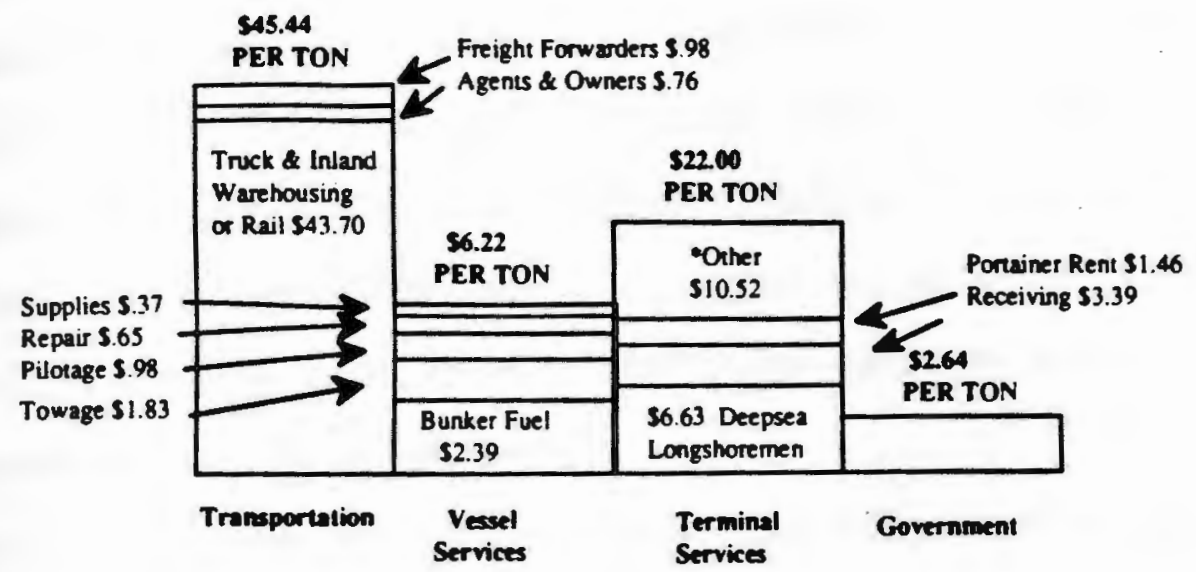

-Includes: Dockage. Wharfage, Overtime, Ramping and Detamping. Transtainer Rent.

Suffing and Stripping. Storage. Space Rent. Linehandling, Refrigeration, and Exta Labor

\section{BREAKDOWN of REVENUE for BULK CARGO}

\section{\$18.27 PER TON}

S15.84 PER TON

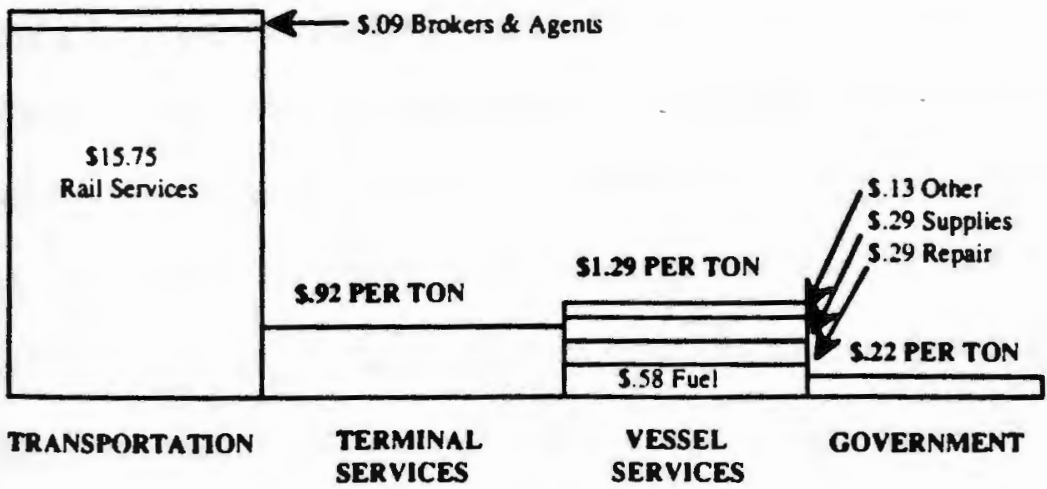

Source: Yochum, Gilbert R. and Vinod B. Agarwal, 1988, p. 43 and 45. 
permit better service. If an individual port has sufficient facility space to immediately allocate a berth and service a vessel quickly, that port may have an advantage over its competitors. Ports always strive to be in this position by providing sufficient and even excess capacity for peak trade periods.

Thus, like other competitive industries, ports will always exhibit a certain degree of over-supply. Given the unique competitive character of ports in the U.S. and their tendency to overbuild, how much overcapacity exists today in the Mid-Atlantic port range from Baltimore, Maryland to Jacksonville, Florida? Does this overcapacity represent significant land use, economic and planning inefficiencies? What policy decisions could be implemented to solve these problems?

As a result of poor port planning, container facility overcapacity can lead to three resulting problems: 1) inefficient use of coastal lands, 2) inefficient use of port and public expenditures, and 3) long-term environmental degradation of adjacent marine resources. Inherently, overcapacity represents a "suboptimal allocation of resources due to overinvestment" (Hikkila, in Hershman, 1990, p. 52). Planning for port expansion becomes a function of monitoring growth, land availability and, most importantly, market conditions. Ports may find it less costly to acquire and develop new container facilities rather than upgrade existing facilities. Expanding land holdings may be less costly than improving operating efficiency within existing facilities due to spatial constraints. Expansion planning in turn adds to the tendency of ports to overbuild without improving operating and land use efficiencies. Port expansion precludes the use of coastal lands for other means and imposes future coastal planning constraints as available land diminishes. Inefficient capacity monitoring not only results in inefficient land use by ports, but may also cause long-term 
environmental degradation from dredging. Further, over-investment of public funds is a result of planning decisions too often made without political review.

According to the United States Maritime Administration, "Some of the port capacity being built today stems from the strong desire to entice carriers to divert cargo from another competing port rather then to serve incremental growth in cargo" (Pisani, 1990, p.37). Port managers argue that freedom to make decisions apart from political review is essential to the proper management of "these business-like enterprises" Journal of Commerce, Friday June 3, 1990, p. 9c). This argument has merit, supporting the preservation of port competition without political interference. If overcapacity is shown to be extensive within the study range, however, the policy relating to the degree of political autonomy should be re-evaluated.

Should ports be allowed to plan for expansion apart from political review? On the state level, ports have been given the authority to do so. Port charters require only that they operate within the margins of improving local economies and increasing cargo throughput. Apart from the permitting process, development is usually not questioned. Ports are public agencies. Is port autonomy consistent with the requirements of public accountability? Because the port system is competitive, expertise is required for effective port management. And, minimum political control is required if the port is to compete freely. Still, to what extent should ports continue to expand as the local benefits of incremental expansion decrease while additional stress is placed on community infrastructure, and coastal land continues to be used up? Any accountable public agency should eliminate its redundant facilities just as any accountable public agency should stress economic efficiency and conservation of land (Hershman, 1978, p. 81). 


\section{Hypothesis}

It is hypothesized that there is significant overcapacity of container facilities among the Mid-Atlantic range that includes the ports of Baltimore, Norfolk, Charleston, Savannah and Jacksonville. Competition among these individual ports has resulted in a tendency to overbuild in order to attract more cargo and revenue (Welch, 1991). This thesis assumes that if overcapacity exists, there may be a need for local and/or regional capacity review by port managers and public officials as part of development planning and permitting. It is further assumed that although other options may exist, capacity review could lead to a more efficient port system.

The ports included within this analysis are all large commercial facilities which utilize large amounts of coastal land. Container facilities require significant parcels of land to operate. In addition, containerization is increasing, and is providing the incentive for ports to expand container facilities. The ports studied have significant land requirements, significant development expenditures, and continue to grow as a result of open competition. For these reasons, it is suspected that the ports in this study exhibit significant overcapacity.

A major issue of this study is whether or not competition leads to overcapacity. It is assumed, because of the historical development and the physical size of the U.S. port system, that a competitive port system is more economically efficient than a federally controlled system. Still, some type of capacity review on a regional level may be necessary in order to encourage economic and land use efficiencies while not impeding port growth. 
A secondary hypothesis, which promotes the need for capacity review, is that port development will continue to exceed container throughput in the region. Forecasts of future container flows do not justify the extent of container development in ports today. Thus, the problem is not short-term.

Rather, it is becoming greater as ports continue to develop container facilities. "We do not have gross overcapacity now, but with today's trend, we're heading down that road "(Kelly, 1987, p. 37). In support of this growing problem of excess container capacity, it is further hypothesized that ports are placing unwarranted importance on container cargo relative to other cargo types.

\section{Justification of Study}

Preliminary research shows that the ports of Baltimore, Norfolk, Charleston, Savannah and Jacksonville collectively operate a total of seven major container facilities with twenty-eight container berths and forty-seven, 40-to 50-ton container cranes. They also utilize approximately 2,000 acres of coastal land for storage. Table 1 shows the facility specifications in the ports studied.

According to published capacity information, a normally operating container berth with 50 acres of backup space has an approximate capacity of 100,000 twenty-foot containers or Twenty-foot Equivalent Units per year(TEUs)(Ashar,1986). A conservative preliminary calculation shows that with 29 berths, total capacity within the study region in 1989 equaled 2,900,000 


\section{TABLE 1}

\section{FACILITY SPECIFICATIONS}

PORT

\section{PORT OF BALTIMORE}

Dundalk Marine Terminal

PORT HAMPTON RHODES

Norfolk Inter. Terminal

PORT OF CHARESTON

North Charleston Terminal

Wando Terminal

PORT OF SAVANNAH

CONTAINERPORT

PORT OF JACKSONVILLE

Blount Island Terminal

Talleyrand Terminal
BERTH

6

10

285 ACRES 8,100 TEU

4

7

479 ACRES 35,528 TEU

3

3

5

6

192 ACRES

4,333 TEU

150 ACRES 4,000 TEU

5

9

245 ACRES 21,856 TEU

3

5

7

180 ACRES N/A

48 ACRES N/A

Source: Courtesy of the Ports of Baltimore, Norfolk, Charleston, Savannah and Jacksonville. 
TEUs while actual cargo equaled only 1,935,198 TEUs. This comparison indicates a 49 percent current excess capacity throughout the range (Figure 3).

Although these figures are based on rough estimates, they support a plausible theory that increased competition among ports for containerized cargo has led to overcapacity (Pisani,1989; and Kelly,1987). Furthermore, preliminary research also indicates that all ports in the study have either completed or are currently planning expansion projects today in order to further increase container handling capacity (See Table 2).

In recognition of related problems in port planning, coastal land use, and environmental degradation, significant overcapacity becomes an even more pressing issue that must be faced. In this study, if significant overcapacity is shown to exist, a re-evaluation of policy and management on a regional or local level is suggested. Therefore, a more definitive quantification of capacity information is required. This quantification will ultimately help resolve policy questions associated with the problem of overcapacity. The purpose of this research project is: 1) to identify the potential problems and implications of coastal land use; 2) to quantify the extent of overcapacity; 3 ) and, to suggest policy solutions which might address some of these inefficiencies.

\section{Overcapacity of Port Container Facilities}

There are many problems related to the definition of excess port capacity. One is perspective. No concrete definition of excess overcapacity exists nor is there a definition of what constitutes a desirable level of overcapacity. Generally, excess capacity is that which exceeds the requirements for peak trade spill-over (i.e. seasonal cargoes) and military 
FIGURE 3

\section{PRELIMINARY REGIONAL CAPACITY CALCULATION v. ACTUAL REGIONAL CONTAINER THROUGHPUT}

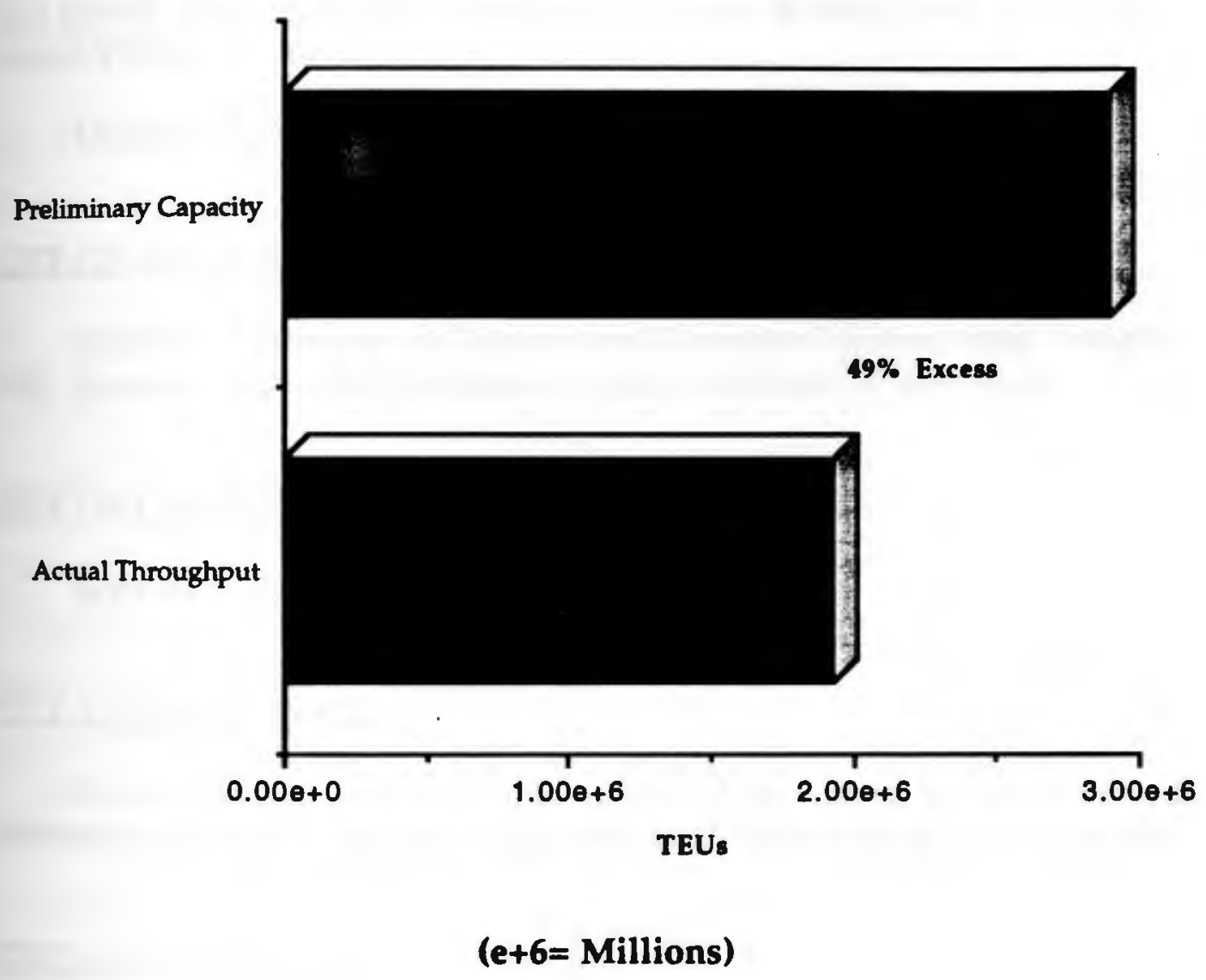

Source: Courtesy of individual ports and author's calculations 


\section{TABLE 2}

\section{SUMMARY OF PORT EXPANSION PROJECTS}

\section{PORT OF BALTIMORE}

Seagirt Terminal- a $\$ 250$ million advanced facility. Facilities include three berths, seven container cranes on 262 acres of filled land. Capacity = 150,000 TEUs annually.

Dundalk Marine Terminal- $\$ 50$ million Redevelopment Project.

\section{PORT OF NORFOLK}

Northern expansion of 26 acres on 11 acres of upland tidal wetlands for 1992. (permits approved contingent upon mitigation of wetlands).

\section{PORT OF CHARLESTON}

Six new cranes

\section{PORT OF SAVANNAH}

Sixth container berth to come on line at the Ocean Terminal with 42 additional acres of container storage and 1600 lineal feet to Containerport.

\section{PORT OF JACKSONVILLE}

Acquisition of three new cranes. Upgrading storage and new facility for Sea-Land shipping services. New federal bridge under construction. 
berthing in time of conflict. However, differing political perspectives complicate the determination of a desirable level of excess capacity. It is important to understand these different political perspectives because they illustrate the complexity of managing the port industry.

\section{Problems Defining Excess Port Capacity}

From a federal viewpoint, a certain level of overcapacity is desirable.

Historically, federal port policy has been linked to transportation and national defense policies (Marcus, 1976). There is a strong federal interest in minimizing transportation costs to shippers as well as providing an excess in capacity to serve national defense interests in times of war. However, federal interests also include overall social welfare functions such as land availability and environmental degradation. This interest is directed at broad national benefits.

The state perspective and that of the individual ports is quite different. Ports are interested in sufficient excess capacity to ensure effective operations and to allow for peak trade periods. Excess capacity is a desirable condition which allows a port to remain competitive. State-run and locally run port interests are rarely concerned with overall social benefit. Rather, a port is primarily concerned with the success of its operation and the opportunity to increase cargo throughput and revenues.

Public concerns, involving available coastal space, public expenditure and the environment, influence the perception that any excess is too much. Public concerns for environmental protection and preservation often conflict with port desires to expand and up-grade facilities. It should be understood that determining the amount of acceptable excess capacity depends upon a 
particular policy setting. Because the level at which excess capacity is reached depends upon a combination of the previously stated three perspectives, management for the prevention of excess capacity should naturally involve these factors. Ideally, there should be a coordination of port operations management and social welfare policy. Unfortunately, the present system of port development leaves decisions about acceptable excess capacity to individual ports. Consequently, port overcapacity extends across various port ranges. The question remains: how much excess should be tolerated by the public when it causes inefficiencies in public expenditure and coastal land use?

\section{Public Port Entities Managed as Private Corporations}

To what extent are publicly owned port facilities accountable to the public? The influence that this accountability should bear on the management of port operations is the central question of this thesis.

Most ports in the United States, with the exclusion of military ports, are publicly owned. The most common form of public port management is the port authority. Public port authorities are created by statute as non-profit organizations with a separate legal personality, the right to hold property, make contracts, adopt budgets, employ its own personnel and function with considerable financial and political autonomy. The Port of New York Authority is described as:

"...a public corporation set up outside the regular framework of federal, state, or local government, and freed from the procedures or restrictions of routine government operations, in 
order that it may bring the best techniques of private management to the operation of a self supporting or revenue producing public enterprise." (The New Jersey Council for Social Studies, 1953, p. 45)

Port authorities can vary in geographic scope from city to entire state jurisdictions. Their actions may conflict with broader public goals regarding environmental protection and coastal management.

The following discussion pertains to publicly owned and operated ports and makes no distinction about the jurisdictional scope of the port. Instead, an argument is made that these publicly owned ports have an inherent prevailing public interest. Accordingly, there should be some public accountability for their actions.

\section{Efficiency: The Conflict Between Business Decisions and Public Interests.}

Efficiency in production for a private firm can be much different than efficiency from a social perspective. Private firms, unless they are regulated to do so, do not normally include social costs such as pollution as costs of production. Efficiency on a private level understates costs and overstates netbenefits. The result is a dichotomy between public interest and business operations which affect public lands.

A general criterion for optimal efficiency occurs when the marginal benefits of production equal marginal costs of production. For a private firm, this condition will be the optimal efficiency point in so far as its individual goals are concerned. For society, the benefits and costs become broader than those of the micro-environment of the firm. Society incurs external costs as a 
result of private operations. In the case of ports these external costs include the opportunity cost of land and environmental degradation. These social costs may not be considered by the public port, since it can acquire land more easily than competing users and it does not pay taxes. Rather, these unpaid costs are forced upon society. Thus, the point at which the marginal benefits and marginal costs intersect to indicate optimal efficiency differs between the public and private sectors. A set of cost and benefit curves for the private firm understates costs because social externalities are not considered (See Figure 4).

Quantity $Q^{*}$ and $P^{*}$ represent an optimal output and price for port development when external social costs are not included. When social costs are considered, marginal costs of development will increase and quantity $Q^{* *}$ is then the optimal quantity at a higher price $\mathrm{P}^{* *}$. In reality, if a port system develops at $Q^{*}$ and does not consider external social costs, then there is an excess quantity of port facilities of $Q^{* *}-Q^{*}$.

While a private firm can have optimal production efficiency, if this production results in negative external costs to society, a socially inefficient condition exists. Since the private sector does not account for the social expenses, their costs are understated from a social perspective.

As quasi-public agencies in a competitive system, ports operate similarly to the private firm described above. If ports are not accountable for social costs, they will operate under a different efficiency condition which is at variance with social efficiency. Inherently, over-investment and subsequent overcapacity in container facilities is due in large part to the fact that public ports operate autonomously as private corporations. Insufficient cost information leads to over-investment and to inefficiency in port development and operations. It is in recognition of the social inefficiency associated with quasi-public ports that information on port capacity should be 


\section{FIGURE 4}

THEORETICAL OPTIMAL LEVELS OF PRICE AND QUANTITY FOR PORT DEVELOPMENT WHEN SOCIAL EXTERNAL COSTS ARE CONSIDERED

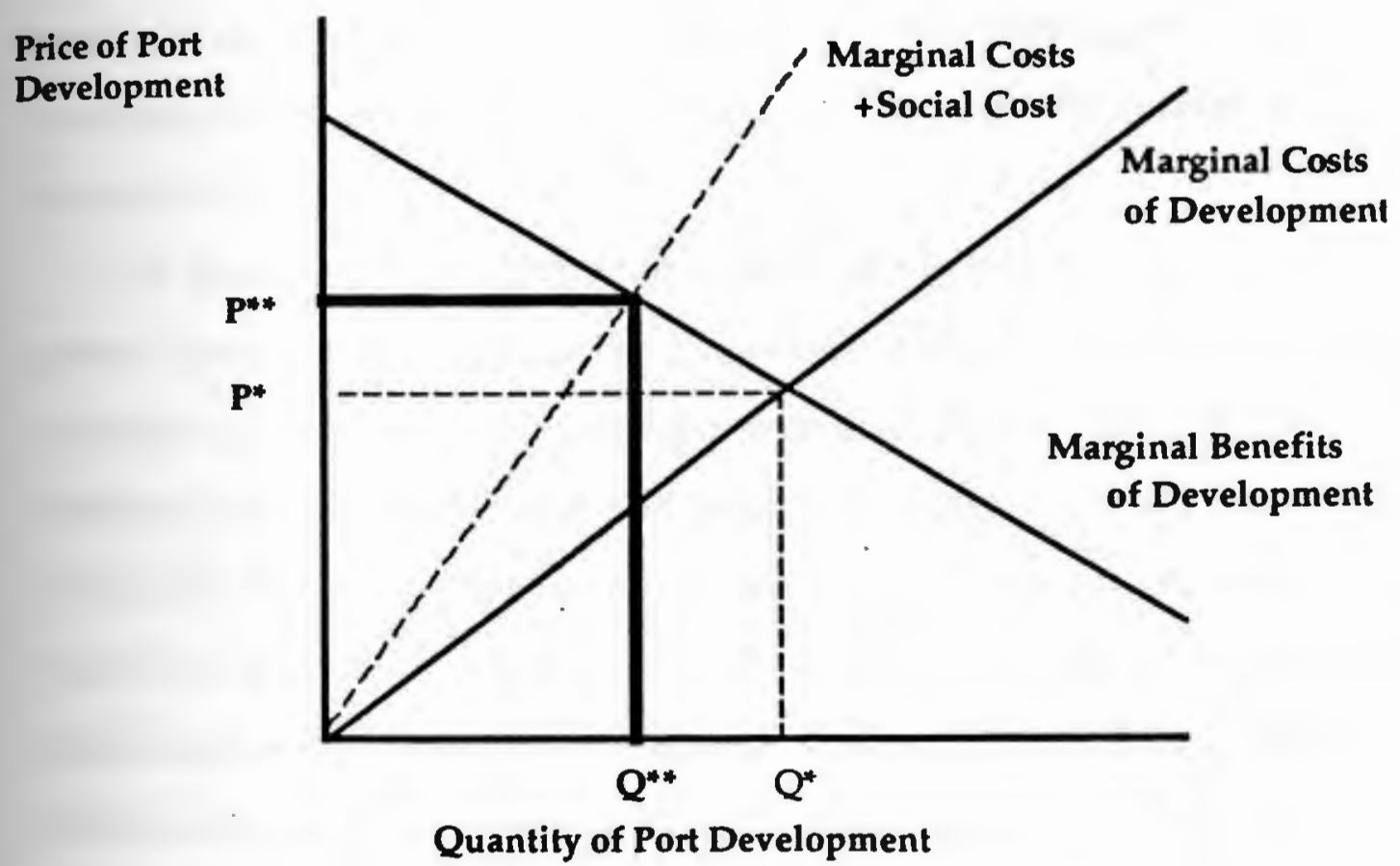

Source: Author's illustration 
made available for coastal planning and management. Ports can then move towards a more socially efficient operating condition.

A public port is often viewed by its community as an important utility (Marcus, 1976). It serves as a focal point for business in the city and has a strong economic and social impact on its community.

While the port industry operates within a competitive market oriented system, it is also a public entity and, as such, is subject to public accountability. Public financing often provides for port expansion and improvements to infrastructure. At the same time, the public is concerned about the impacts of the port facility on surrounding communities. While these impacts may be beneficial, such as the economic expansion within a port region, it may also have negative consequences such as those mentioned with respect to overcapacity.

A prominent characteristic of a public utility is that it operates at its greatest efficiency as a monopoly. The reason is that economies of scale result in decreasing unit costs with respect to increased output. The capital intensive nature of the present port industry mandates that the more traffic moving through a port, the lower the cost per ton. From a national or regional standpoint, duplication of facilities that serve essentially the same region reduces their economic efficiency. This is particularly evident in harbors with competing ports, such as the Ports of Long Beach and Los Angeles, and states such as California and Washington which have more than one port competing for cargo within state boundaries. The larger a port is, the greater are the advantages that it can realize through economies of scale. Economies of scale are achieved within the port through greater efficiencies and lower costs per ton of throughput. 
However, large ports are particularly susceptible to public scrutiny. Ports within the same state or harbor that compete against one another reduce their economies of scale and result in inefficient government expenditures and in higher per unit costs. Other costs to the public include the opportunity costs of the land utilized in the construction of unnecessary facilities. It also results in the public employment of duplicate personnel and operational services that could be more productive if employed elsewhere. These all represent inefficient use of public funds.

From a national and regional standpoint, this higher than needed per unit cost is undesirable because it is passed on to the shipper resulting in elevated shipping costs. In the end, some potential cargo may not flow through the U.S. port system. The federal government also has an interest in the economic vitality of the port industry because the nation benefits from port economic activity (Brinson, 1980).

There is an additional layer of complexity which surrounds the issue of managing public port entities as private corporations. State governments, local communities, and port authorities are concerned with the economic vitality of their ports within the industry. This has led to the present competitive system. At the same time, there is a public interest with respect to efficient coastal management and environmental protection. In other words, there is a conflict between economic motivations and environmental concerns. Yet, at the present time, there is no one to coordinate these actions. The environmental permitting process, although it impacts national and regional economic activity, does not review industry requirements for capacity growth. There is a desire at the federal level to ensure the protection and conservation of the nation's coastal zone. It is conceivable that if environmentally acceptable, a port development permit application may be 
approved even if current capacity needs are sufficient within the existing port. The Army Corps of Engineers, under Section 401 of the Clean Water Act currently accepts comments about the effects of a proposed development from environmental agencies such as the Fish and Wildlife Service. It does not, however, review information concerning the capacity requirements of the port in its Section 401, Clean Water Act permits or its Section 10, Rivers and Harbors Act permits. Such information is relevant and useful during permit review. Although there may be other relevant options to reduce the port overcapacity situation, the scope of this thesis relies on existing federal legislation and the mechanisms they provide (the ability to comment) that address overcapacity. Without capacity information, permitting agencies are not making thorough reviews of permit applications. This inefficiency in permit review shows the government inability to prevent unnecessary development on coastal lands.

The loss of coastal ocean space from the construction of unnecessary container facilities is not in the public's best interest. In addition to the loss of coastal ocean space, there are additional effects which affect the public in a negative way. While increased container handling capability may bring positive economic benefits to the surrounding port community, there also may be detrimental effects associated with this construction, such as increased pressure on the highway and rail infrastructure.

There are also questions surrounding continued construction of container facilities. Many ports are continuing to build facilities to service increased intermodalism. Intermodalism is the practice of moving cargo from place to place utilizing several different modes of transportation. Much of the capacity that some ports are building seeks to capture cargo that would not normally flow through the port region. While the port entity and the 
public realize a profit, the primary economic benefits of this cargo throughput are not felt within the port community in the same manner as cargo bound for the port region. Thus, some ports reach a point where the incremental benefits of port expansion begin to decrease.

The question remains, should ports compete for cargo not destined for the port's region? Obviously, the role of a non-profit public port should not primarily be to earn a profit at the expense of society. If it does, it then can invest profit in the local society. It should function as a self-sustaining economic entity much in the same way that public utilities function. It is this clash between free market economics and public welfare that guides the recommendations for managing an ever-growing overcapacity among the nation's container ports.

The situation in San Pedro Bay, California illustrates the conflict. The recently completed 2020 plan for the Ports of Long Beach and Los Angeles in response to the projected increase in Pacific Rim trade represents an attempt to manage inadvertent overcapacity and inefficient use of coastal ocean space with respect to port growth. Coastal ocean space consists of coastal lands, near coastal waters and the interface between the two. The plan also attempts to alleviate the stress placed upon transportation infrastructure as a result of new development. But this plan incurs specific costs that the public will bear. The estimated construction and implementation costs are estimated to exceed five billion dollars (Hall, 1990). Despite many projected benefits, there are many costs associated with the plan which are not easy to calculate or predict. The resulting environmental damage and coastal ocean space utilization sometimes associated with port development should arouse public concern. In addition, these ports are by no means assured access to the projected increase in trade, and this construction may, despite planning, result in 
overcapacity and underutilized infrastructure. From a regional perspective, other ports may be in a better position to handle the projected Pacific Rim trade and may serve this trade more efficiently at a reduced cost.

While it is encouraging that these ports are at least planning on a small scale, regional basis, the projected increase in trade may to effect the entire West coast port range. Management of container facility capacity at this level can result in better efficiency in coastal ocean space utilization and improved economic efficiency in existing ports throughout the region.

In order to improve the public accountability of public port actions and improve the management of excess overcapacity, there are many actions which could be taken at the federal, regional and state levels. The next sections explore the present roles of these governmental levels with respect to the management of overcapacity and suggest what roles they could play in the future.

\section{Federal Port Policy and Overcapacity of Container Facilities}

Federal policies pertaining to port development have historically been institutionally fragmented and short on focus. Federal port policy has been limited by Article 1, Section 9 of the Constitution which states that:

"No preference shall be given by any regulation of commerce on revenue to the ports of one State over those of another: nor shall vessels bound to, or from, one State, be obliged to enter, clear, or pay duties in another." 
This paragraph limits federal and state regulatory powers and prevents them from imposing either a discriminatory or competitive bias. Other factors have prevented the assertion of any strong federal port policy. The structural fragmentation and jurisdictional conflicts inherent in the congressional committee structure tend to constrain unified port development policy.

Most federal port policy takes place at the regulatory level. Federal agencies affect port development in three ways: (1) through the allocation of federal funds for port related projects; (2) through the implementation of regulations that control the siting and operation of container facilities; and (3) through the formulation of policy that directly and indirectly affects ports.

Much of federal regulation and policy deals with environmental effects. The environmental regulatory responsibilities imposed on ports are fragmented and split among different agencies of the federal government, such as the Army Corp of Engineers (COE), the Coastal Zone Management Program, and the Environmental Protection Agency (EPA). This fragmentation serves as a barrier to unified policies pertaining to the national port industry (Marcus, 1976). The Federal deregulation of transportation industries and the change in the nature of the traditional "partnership" pattern of port development have also prevented any strong assertion of federal port policy (Brinson, 1980).

Yet, it can be argued that there is a strong need for a federal port policy. As the ever present effects of an intermodal transportation system take hold and the competitive pressures of containerization are felt by the nation's ports, there is a strong need to prevent excess capacity of container facilities at both the regional and national level. This need is expressed in the national desire to provide the best possible service at the lowest possible cost in order 
to take advantage of the opportunities presented through economies of scale. There is also a national need to operate in a socially efficient manner and to minimize the detrimental environmental effects of unnecessary expansion. Environmental degradation is a national concern. There is a strong national desire to preserve, protect and develop the marine coastal environment. There has already been significant federal participation in land use planning in the coastal zone in order to provide a balance between conservation and development (Holmes, 1980).

Federal policy has shifted toward increased cost sharing between state and federal governments. The federal government also has a monetary interest in preventing overcapacity. Federal money is often spent directly or indirectly on projects affecting port development. These projects range from highway construction to channel and harbor maintenance which effect port operations.

\section{The Federal Role in Port Development}

What should be the federal role in port development with respect to overcapacity in container facilities? As mentioned previously, there is a desire at the federal level to maintain a certain level of excess capacity. Its importance was exhibited by the use of ports during the Gulf War in 1991. At the same time, there is a demand for the orderly development of an economically efficient transportation network of ports, railroads, and highways which does not impose significant social costs on the nation with respect to environmental degradation and inefficient use of public funds.

The federal government can play a stronger advisory role in supervising port development without interfering with the competitive 
nature of the industry. In some respects, the formulation of a comprehensive national port policy would be useful to guide national port development as it expands to meet the growing demands of intermodalism and world trade. It is recognized that there are many difficulties involved in the formulation of such a federal port policy. The integration of existing federal policies affecting ports is a good place to start.

A coordinated approach within the environmental permitting and regulatory process with respect to port policy would be beneficial to quell the growing overcapacities at regional and state levels. The integration of regulatory responsibilities and policies towards ports would offer the federal government increased controls over coastal land use which results in overcapacity. For example, environmental impact statements prepared under the National Environmental Policy Act could be required to recognize regional forecasts of overcapacity with respect to the requirements for construction. The Coastal Zone Management Act could be used to facilitate port planning with respect to overcapacity at the State level. Within their permit reviews, the EPA and Army Corp of Engineers should coordinate efforts with other agencies in order to ascertain required dredge and fill operations to help achieve desired levels of excess capacity.

The federal government should play an ongoing role at the regional level with respect to assessing port container capacities. This review process and the required supervisory role could be handled by the Maritime Administration (MARAD). MARAD could coordinate environmental regulation of various federal and state regulatory agencies so as to minimize detrimental effects of overcapacity at the regional level. It could also serve as technical consultant and conduct the capacity review. MARAD could sponsor annual or semi-annual meetings for port managers, state officials, and the 
public in an attempt to manage container overcapacity in a more efficient manner.

\section{Federal Jurisdiction and the Regulation of Port Land Use}

Federal jurisdiction in port land use is limited to dredge and fill permitting through the Rivers and Harbors Act of 1899 and section 401 of the Clean Water Act, 1972. This permitting process serves to protect the national interests of navigation, water pollution and wetlands destruction. Federal authority over port facility expansion does not exceed these national concerns. In other words, the federal government is not directly concerned with efficient use of coastal lands, only that land use does not impede navigation or result in unnecessary destruction to the environment.

Although port policy in the U.S. has favored state control, there are a few federal mechanisms under the jurisdiction of the Army Corps of Engineers and the Environmental Protection Agency which control port development. To protect national interests in environmental protection and navigation, proper permit approval is mandatory for any development in U.S. waters or adjacent wetlands (Kalo, 1990).

The Rivers and Harbors Act of 1899 established Army Corps jurisdiction by requiring Corps approval of any construction in waters of the United States. According to Sec 10:

"The creation of any obstruction not affirmatively authorized by Congress, to the navigable capacity of any of the waters of the United States is prohibited; and it shall not be lawful to build any wharf [or] pier in any port [unless] authorized by the Secretary of the Army"(Kalo, 1990, p. 172). 
The Rivers and Harbors Act created federal jurisdiction over navigation in U.S. waters and required ports to apply for any development in these waters. Since 1899, there has been considerable debate as to what constitutes waters of the U.S. and what development may be regulated by the federal government through the Rivers and Harbors Act. Generally, port development has always required federal approval due to its navigational implications. As a result of increasing environmental concerns during the 1970s, the Army Corp's jurisdiction over coastal development was extended.

The Clean Water Act went into effect in 1972. Section 401 of the Act mandated a separate permit for dredge and fill activities. The court in Zabel $v$. Tabb recognized the damaging effects of dredge and fill on coastal ecosystems and ruled that the Army Corps, in consultation with other relevant agencies such as the Fish and Wildlife Service, could reject a Section 401 permit based upon environmental considerations (Kalo,1990). While the Clean Water Act is primarily administered by the Environmental Protection Agency, Sec. 401 is administered by the Army Corps of Engineers. The sec.401 dredge and fill permit, in effect, serves as a federal check against state and local port development which may damage the the environment. The permit review considers dredged spoil site disposal, overall environmental impacts, practical alternatives and any proposed mitigation.

Mitigation is one way to address natural resource damage. Proper compensation is determined during the review process and is a function of the type and extent of damage [as well as to the extent practical]. Ports offering some type of mitigation effort may be favored in permit review. For example, the Port of Norfolk is mitigating the loss of 11 acres of wetlands as a result of its northern expansion by artificially creating wetlands. With the no net-loss national policy concerning wetlands, mitigation has become a means by 
which ports can carry out development on sensitive wetlands. Wetlands creation may help in mitigating the environmental effects of port development, but it can often be costly and uncertain. Often, mitigation [the attempt to obtain a favorable modification of damages to wetlands] is unsuccessful and costly. Development could be completed while the mitigation effort fails, and the effects of completed development cannot be reversed. A failed mitigation effort in such a case represents a cost to the environment. It is in the best interest of ports and society to justify the costs of development by first proving that expansion is necessary.

According to Environmental Protection Agency 1989 regulations:

"no discharge of dredged or fill material shall be permitted if there is a practical alternative to the proposed discharge which would have less adverse impact on the aquatic ecosystem, so long as the alternative does not have other significant adverse environmental consequences"(Kalo, 1990, p. 275).

According to the definition of practical alternative, "an alternative is practical if it is available and capable of being done after taking into consideration cost, existing technology and logistics in light of overall project purposes."(Kalo, 1990, p. 275)

Unless actual port technology and logistics are considered during permit review, proper consideration of potential practical alternatives to development will not occur. EPA regulations obligate federal regulators at EPA and the Army Corps to consider all relevant information, which could include figures that demonstrate productivity and the capacity requirements of the port. Again, MARAD could lend expert assistance, and provide technology and logistic information in this capacity. The following flow 
chart is an example of how the permitting structure for port development could be facilitated (Figure 5).

The federal permitting process plays a key role in a port's ability to expand. Economic implications to a port community from a permit denial based solely upon environmental considerations could be significant. The U.S. Supreme Court recently began to recognize that a property owner could not be denied economic use of his land (Kalo, 1990). The Court implied that economic considerations should be included in permit review for development on, or adjacent to wetlands. For private land owners, it may be fair to consider the economic viability of land use. In Sears 0 . Berle the Court was limited to determining the intended economic use of the land and not the viable alternatives of private land use (Kalo,1990). On public port lands, however, economic alternatives could be included in a permit review to satisfy public accountability. Federal statute and precedent mandate that economic considerations and viable alternatives should be considered during a permit review. In essence, federal law suggests the use of tools such as capacity review, which considers both viable alternatives to development and indirect economic implications.

The analysis presented in this thesis is an example of the type of review which would be helpful in determining whether a practical alternative exists. For example, if capacity analysis indicates that a port has significant excess capacity, in certain instances, the alternative to not expand may be considered practical. 


\section{FIGURE 5}

\section{RECOMMENDED ORGANIZATIONAL PERMITTING STRUCTURE}

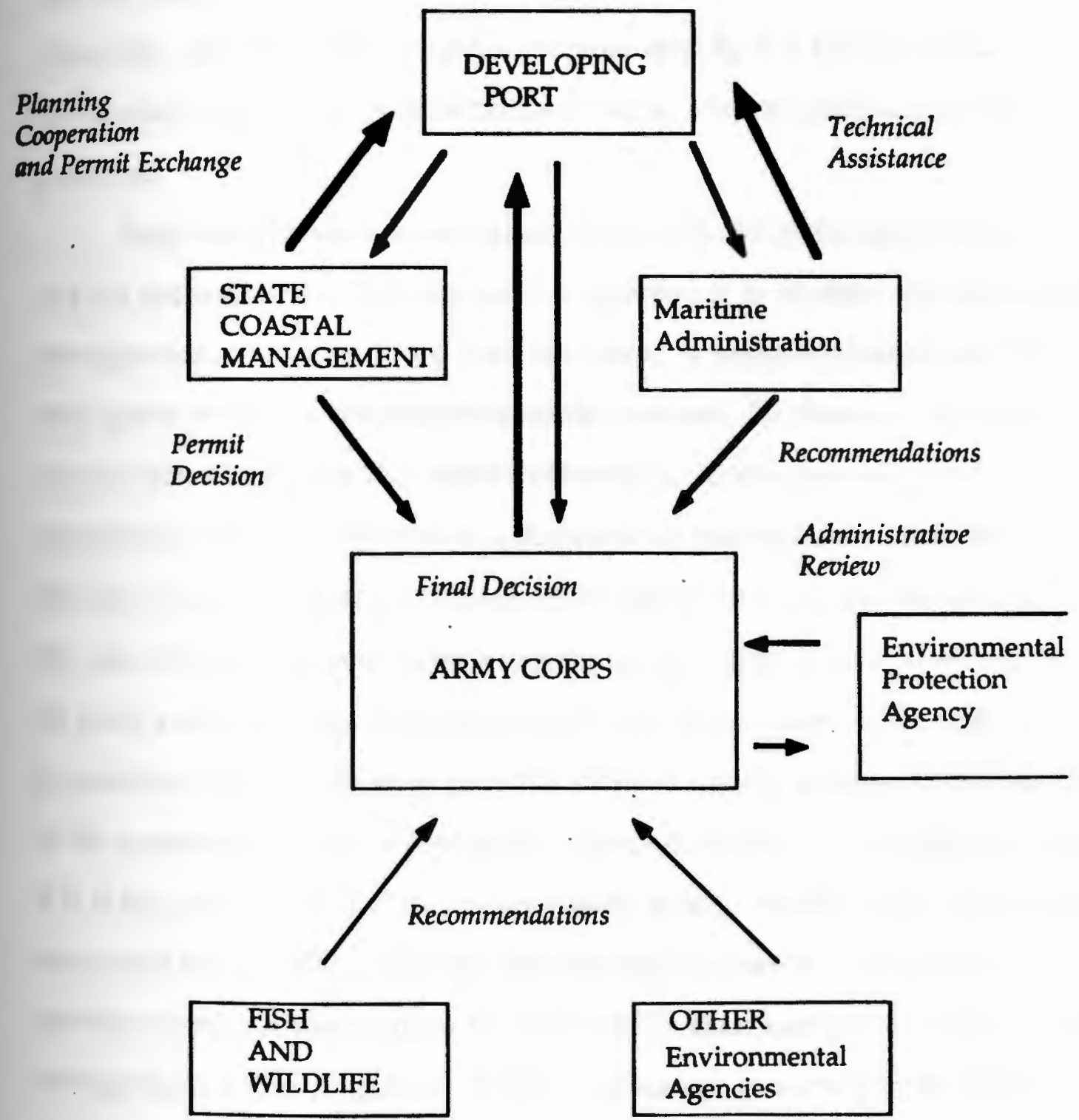

Source: Author's illustration 
State/Regional Policies and the Management of Overcapacity

State port policy in the U.S. is administered by individual state port authorities. The policy directives outlined in most port charters focus upon increasing cargo throughput and improving local economies. Any policy relating to land conservation may exist in a port charter or as an inherent factor of public accountability. The assurances of any such policy ,however, can not be guaranteed due to the lack of a reliable political mechanism. Generally, port development goes unchallenged by the public due to assumptions that all port development is required to maintain competitive positions.

Regionally, states are not required by federal law to cooperate or engage in joint management. In a competitive system, it is unclear whether regional management, involving more than one state, is mutually beneficial. Each state gains economic benefits from trade revenue. In theory, inter-state competition distributes this wealth efficiently. Consequently, port competition presents barriers to a cooperative management structure. Efficient inter-state port management would result in cargo allocations. In the case of containerized cargo, regional management would also require that all ports agree on cargo allocation decisions. The problem with this proposition is that each state port has different goals, mainly involving gain at the expense of others. Potentially, a port can attract all the cargo in a region if it is big enough. The main question here is why sacrifice any cargo, when you could have it all? Although the existing competitive system may provide economic justification for state rather than regional or federal port management based on market theory, it does not provide for the efficient 
allocation of coastal land. For this reason, capacity review on a state and regional level is necessary.

But, there are barriers to successful state and regional management structures. Regional management cannot occur effectively unless ports have the same goals. Until ports can be convinced that regional management will result in benefits to all involved, cooperative management will not occur on a voluntary basis. There have been examples of this cooperation, but they have fallen short of achieving better land use efficiencies from a public perspective (Hershman, et al., 1978). In response to the charges of overcapacity in the 1970s, and due to the increasing difficulty in financing container facility development, voluntary cooperative management has taken place in the state of Washington (Hershman,et al., 1978). The Cooperative Development Committee (CDC) of The Washington Public Ports Association (WPPA) was formed to review port projects. Although it functioned particularly well in sharing capacity information among ports, capacity information was utilized by non-member ports and there were no sanctions for non-compliance (Hershman, et al, 1978). CDC in Washington was an attempt at preventing redundant facilities and improving efficiency; however, the Association did not coordinate planning efforts with other public officials and thus precluded any effective regional management (Hershman, et al., 1978).

Regional or coordinated state management must consider port needs in conjunction with other social welfare functions, such as other uses of public land. Clearly, it would be useful to involve port managers, regulatory officials, and the public in government in the decision-making process. Whether or not such management should be mandated depends upon the extent of the overcapacity problem. It is suggested that the competitive port 
system in the U.S. is the best system available and should remain intact. To prevent potentially wasteful use of public coastal space, however, policy must be reevaluated and designed to meet the social goals of land conservation.

Understandably, ports are not primarily concerned with land conservation. As a public agency competing for international trade, the port is ultimately concerned with sustaining its viability and competitive success. Permit review is left to other state agencies. These agencies do not base their decisions upon a port's productivity and capacity information. While assuming that a port requires expansion, factors such as land conservation and environmental concerns form the basis of local governmental decisionmaking. Perhaps this check is sufficient. However, a better decision-making process involving cooperation between port management and other public officials could occur if local government and other state agencies involved in land use development were provided with capacity information. Port activity and coastal land use go hand in hand. Port and coastal space management should therefore be coordinated. Not only will the port benefit from accurate productivity and capacity assessment, but inter-agency review of this information can facilitate decisions concerning coastal space utilization.

An important point to be made is that regardless of accurate productivity and capacity monitoring, overcapacity may still occur. Port expansion and improvement requires many years of planning and development. Ports are forced to develop according to anticipated cargo rather than proven growth. Thus, there is bound to be a certain amount of excess capacity. The goal of public policy should be to decide how much excess is allowed. This determination can only occur with a cooperative effort between public ports and other public officials once all pertinent port information is made available for study. A thorough inter-agency capacity 
review will lend itself to maximum attainable social planning efficiency within the competitive framework. Thus, close cooperation provides a mechanism for limiting overcapacity on a local and regional level.

\section{Summary}

Inter-port competition in the U.S. has resulted in an expansive port system and the development of large container facilities. Within a region, duplicate facilities create overcapacity. This overcapacity represents social inefficiencies in coastal land utilization, public expenditures, and environmental degradation. As container development continues, expansion by politically autonomous public ports threatens to increase these inefficiencies. A certain level of autonomy must be preserved so that ports can operate effectively in a competitive world economy. As public entities, ports are accountable for their actions. In order to prevent the social inefficiencies created by excess capacity, a policy designed to link port management with the environmental regulatory system is needed.

A capacity review should become part of a coordinated state or regional planning effort as a means to allow for more efficient coastal space utilization. Such a review is good public policy. Perhaps it is time to draw the line with respect to total port autonomy. Port activities can concurrently increase economic benefits to a region while incurring heavy social costs. With better planning that attempts to strike a balance between development and conservation, the future will bring more efficient use of the nation's dwindling coastal ocean space and maximize the benefits of its use to society as a whole. 


\section{CHAPTER TWO \\ CONTAINERIZATION AND PORT DEVELOPMENT}

During the 1950s, containers were introduced in the shipping industry. Subsequently, a technological revolution began which has pervaded all areas of the transportation and trade industry. Unitization of cargo has provided for faster handling of cargo at ports. The container unit can be loaded directly onto truck chassis or rail cars for greater transport efficiency. Reduced pilferage and cargo damage are other advantages of containerization. Since its introduction in the 1950 s, container cargo has grown to approximately 70 million TEUs per year worldwide (Containerization International Yearbook, 1989). This growth has led to the development of many container facilities throughout the U.S. Ports are continually developing these facilities in an effort to increase cargo handling and revenue generating potential (Dowd and Leschine, 1990). The competitive U.S. market structure has resulted in excess capacity as ports continue to expand their container handling capabilities (Kelly, 1987). Competition can normally be viewed as being beneficial to both consumers and producers. However, because the U.S. port system does not operate under pure laissez-faire economic principles, competition may lead to over-supply of facilities, and to excess capacity.

\section{Containerization}

Containerization refers to the packing of general cargo into twenty-foot metal containers (TEUs) or forty-foot containers (FEUs). This unitization was 
first utilized on a wide scale in the 1950s. Containerization initiated a revolution in shipping technology as it facilitated cargo movement between ports and improved shipping efficiency. Because containers can be directly loaded onto truck beds and trains from ships, pilferage of cargo as well as cargo loss were reduced. Quicker off-loading and loading brought about by containerization attracted ports and shippers alike to adapt to the new technology.

Today, containerization of general cargo which formally moved as break-bulk cargo, such as coffee, is the rule rather than the exception. Containerization has grown steadily since the Fifties while contributing to improved shipping and port technologies. Shippers and carriers now operate vessels that can hold nearly 5,000 containers per voyage. The economies of scale created by these vessels increase operating efficiency. Barge-carrying vessels such as LASH (lighter aboard ship) and SeaBee vessels, can load and unload barges full of containers. Rather than transferring cargo from large vessels to small vessels or to feeder barges, barge-carrying vessels can unload the barge itself. Barge-carrying vessels save trans-shipment costs in transit as well as expensive port fees. In response to the growth of containerization, port technologies have advanced accordingly so as to accommodate the demand by port users for container handling facilities.

Specially designed container cranes are required to handle container cargo within a port. They are capable of handling 35 to 40 containers per hour (Containerization International, 1987). Newer technology now provides cranes that can handle 50 boxes per hour (Container News, 1988). Ideally, once a box is off-loaded from a vessel, it can be placed directly on a truck chassis or rail car to continue on its trans-shipment route. Due to moderate time and logistic inefficiencies, however, much of a vessel's cargo is placed in 
a container yard short time storage until it is claimed, checked through customs and shipped to its final destination. Also, storage space is required for cargo that is to be loaded onto a vessel for water transport. Due to large capacity container vessels and transshipment lag times, some $\mathbf{3 0}$ to 50 acres of back storage is required per container berth (National Research Council, 1976). In addition to this large amount of land, 800 to 1,000 foot berths with channel depths of 35 to 40 feet are required to accommodate the container ships of today (Pisani, 1989).

Variable yard operating systems are utilized by ports which result in variable land use efficiencies per acre. There are four basic types of operations: chassis, straddle carrier, yard gantry and top loader.

In the chassis system, containers are stored on truck chassis. This operation allows trucks to quickly attach to a chassis and quickly remove containers from a port. Typical land use efficiencies associated with the chassis system are 70 TEUs per acre (Boschken, 1988). A chassis based yard storage system can not handle as many containers per acre as a stacking system. It may seem, then, that the chassis system is not as efficient as a stacking system. But, the speed of cargo transfer in a chassis yard from ship to shore, port to destination and vise versa makes this system equally efficient over time per acre as other systems of container storage.

Straddle carriers transport containers from the apron to the yard and from the yard to truck or rail. The typical efficiency associated with straddle carrier systems is 168 TEUs per acre (Boschken, 1988).

Yard gantry systems allow the most land use efficiency at 325 TEUs per acre (Boschken, 1988). Yard gantries allow for higher stacking and thus for more containers per area. Similarly, top loader systems have land use efficiencies of 240 TEUs per acre (Boschken, 1988). 
From a strictly land use perspective, stacked systems involving yard gantries, straddle carriers and top loaders are more efficient than chassis based operations. A Chassis system's low land use efficiency may be made up in yard productivity. Chassis can be moved in and out more quickly and therefore may be no less efficient than stacked operations in container yards. Thus, port overcapacity is only partially a function of container yard land use efficiency. A combination of factors including land use efficiency, yard productivity and berth productivity influence the extent of overcapacity.

Another result of increased containerization has been the reduction of manual labor within ports (Gilman, 1987). Containerization is capital intensive as opposed to the labor intensive loading and unloading before the advent of container technology. This trend continues as ports focus more of their resources onto container facilities.

One major characteristic of containerized cargo is its relatively higher value per ton compared to other break-bulk and bulk cargoes. Ports can charge more per ton for this cargo. They can generate more revenue by attracting more container cargo. Because of higher potential revenue and the growth of containerization throughout the industry, capital intensive container facility development will likely continue to replace longshoremen. While this development is continuing, the externalities of the container revolution must be addressed. In the long-run, the loss of longshoremen jobs may prove to be a positive externality. Increased port efficiencies result in increased cargo revenues and promote positive secondary employment impacts throughout the port community. In addition, former port labor can be retrained making them more productive in an economic sense, than if they continued to work while not utilizing the modern technology. 
The negative impacts on coastal land use from container facility development is the impetus for this thesis. It is an established matter of practice that ports dredge and fill coastal lands and wetlands in order to provide adequate paved storage yards for containers, extended berths and deepened channels. This practice is necessary for efficient container handling. While dredge and fill activity is regarded as environmentally degrading, it is necessary to a certain extent to accommodate increases in the size of vessels engaged in international trade. The competition among ports for container cargo tends to lead to overdevelopment as independent autonomous port authorities attempt to provide better services and more storage and berthing space. These trends require that more attention be directed toward the possible negative effects of overdevelopment within United States port system.

\section{Container Importance}

The need for capacity review on a local or regional level is supported by the increasing level of importance that ports are placing on containerized cargo. In order to remain competitive in the shipping industry, U.S. ports have to accommodate the growing amount of containerized cargo being shipped on the oceans, Great Lakes, rivers and waterways. Between 1985 and 1989, container tonnage increased from about 12 million short tons to over 20 million tons among the ports being studied (See Table 3) (AAPA,1991).

Container cargo increases represent the commitment of more land and

financial resources by ports toward container facility development. The increased use of port resources does not present a problem to society. But, in a 


\section{TABLE 3}

\section{NUMBER OF CONTAINERS (TEUs)}

Port

Baltimore

Hampton Roads

Charleston

Savannah

Jacksonville

Average Change
1985

709489

299532

431040

368773

80621
1990

569000

685295

795385

376295

126319

\% change

$$
\begin{array}{r}
-19.80 \\
128.79 \\
84.53 \\
2.04 \\
56.68
\end{array}
$$

$50.45 \%$

Source: Courtesy of the American Association of Port Authorities 
policy setting, when ports exhibit overcapacity, problems associated with those previously mentioned are likely to continue into the future.

The importance of containerized cargo to a large port is not in doubt. Containerization has become the preferred means of transporting manufactured goods and more effort is being put into this area of shipping than any other. Nevertheless, the growing emphasis of ports with regard to containerization has several implications which concern this study.

It has been discussed in this chapter that container facility development requires a large amount of dredge and fill activity which can be detrimental to coastal ecosystems. In addition, these facilities require large capital investments. If the analysis in this study shows that there is sufficient existing container capacity at ports to handle current and future cargo demands, additional development on a large scale will be wasteful. Further, the following results indicate that the problems associated with overcapacity are not going away. Instead, they are intensifying.

\section{Location Quotient}

Location quotients have been used to illustrate the relative degree of importance that ports in this study are placing on container cargo. Originally used to measure the movement of populations in geographical locations, this method was used by Kula and Marti in a prior port study (Marti, 1982, and Kula 1986). The following formula yields a ratio which represents the importance of container cargo to an individual port compared to the entire region. Cargo tonnage figures obtained from the American Association of Port Authorities are utilized in the current study. The formula can be expressed as: 
Relative importance $=(x c / x t) /(Y C / Y T)$

Where: $\mathrm{xc}=$ individual port container cargo

$\mathbf{x t}=$ individual port total cargo

$\mathrm{YC}=$ total regional port container cargo

$\mathrm{YT}=$ total regional port total cargo

A ratio less than 1.00 indicates that containerization at an individual port is less important in comparison to containerization within the region on the whole. A ratio greater than 1.00 indicates that containerization at an individual port is more important than it is to the region. The results demonstrated in Table 4 and the accompanying Figure 6 show that all of the ports except Baltimore and Savannah have placed increasing importance on containerized cargo since 1985.

\section{Competition Among Container Facilities}

All five state-run ports that were studied operate in competition with each other. Through the marketing of various services offered by each port to its port users, competing ports continuously attempt to increase cargo tonnage (throughput) and revenues. By providing the most advanced container handling technology in addition to expanding cargo storage capability, ports are more likely to achieve their major goals. As they succeed, competing ports attempt to "out-do" each other by focusing their resources on expanding facilities and deepening channels and berths to accommodate new generations of container vessels, by providing more high technology container cranes and storage yard equipment. Similar to other competitive industries, ports exhibit a certain degree of over supply. The possibility that over supply of container facilities represents a waste of public funds and coastal-land leads to the present analysis. 


\section{TABLE 4}

\section{CONTAINER TONNAGE V. TOTAL CARGO IN SHORT TONS}

\begin{tabular}{lrrrr} 
& \multicolumn{1}{c}{$\begin{array}{c}1985 \\
\text { container }\end{array}$} & \multicolumn{1}{c}{ Total } & \multicolumn{1}{c}{$\begin{array}{c}1989 \\
\text { container }\end{array}$} & \multicolumn{1}{c}{ Total } \\
Baltimore & 5088270.0 & 26096000 & 4262306.4 & 31025000 \\
Charleston & 3085677.1 & 6792000 & 6181668.9 & 9094000 \\
Jackeonville & 844515.1 & 4248000 & 1927901.8 & 548900 \\
Hampton & 346515.4 & 57074000 & 5387093.8 & 63976000 \\
Savannah & 3281709.2 & 9224000 & 3034356.6 & 10308000 \\
& & & & \\
TOTALS & 12646686.8 & 103434000 & 20793327.5 & 119892000
\end{tabular}

Source: Courtesy of the American Association of Port Authorities 
FIGURE 6

\section{LOCATION QUOTIENTS OF}

\section{RELATIVE CONTAINER IMPORTANCE}

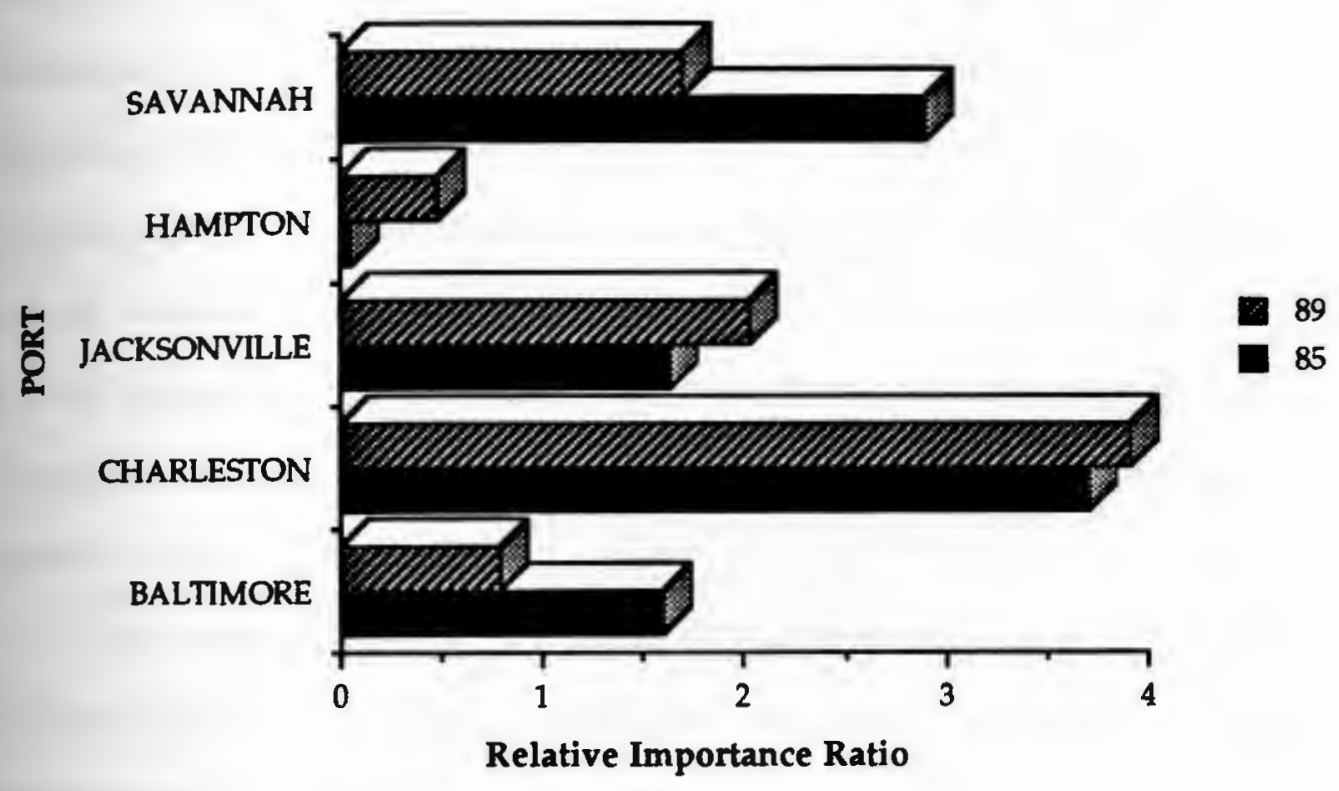

Source: Author's calculations 
Without impeding market-efficient competition between inter-state port authorities, the goal of this analysis is to present a method for analyzing regional port capacity. In this way an effort to provide better management within each separate port authority and to some extent in cooperation with all port authorities could achieve maximum operating efficiency.

It has been argued that the level at which ports compete is declining, i.e. that barriers to entry are becoming greater, limiting the ability of smaller ports to compete (Talley, 1988). As a result of the high cost of port development, an argument can be made that larger ports are better able to fund such development while smaller ports cannot. While this may be true in some instances, it has not occurred in the mid-Atlantic coast range. As seen in market-share analysis (See Figure 7), there has not been dominant growth by any one port. In fact, the indication that over-supply exists throughout the region shows that the level of competition may indeed be increasing (See Table 5).

The deregulation of the ocean transportation industry has been one of the causes of increasing competition among ports. In 1984, the ocean transportation industry in the United States was deregulated so that it could compete more freely and offer internationally competitive prices. The effect on ports was that land and sea shippers and carriers could pick and choose at which ports to call. Intermodal rail and trucking competition led to more variability in trans-shipment of cargo, and ports became uncertain of where, when, and how much cargo throughput they could expect. One way they could affect throughput, aside from facility leasing agreements with private operators, was to expand and improve container cargo facilities. Still, they could never be assured of stable long-term cargo throughput. Intensified competition among the entire transportation industry, as a result of 


\section{FIGURE 7}

\section{7-1989 THROUGHPUT COMPARISON}

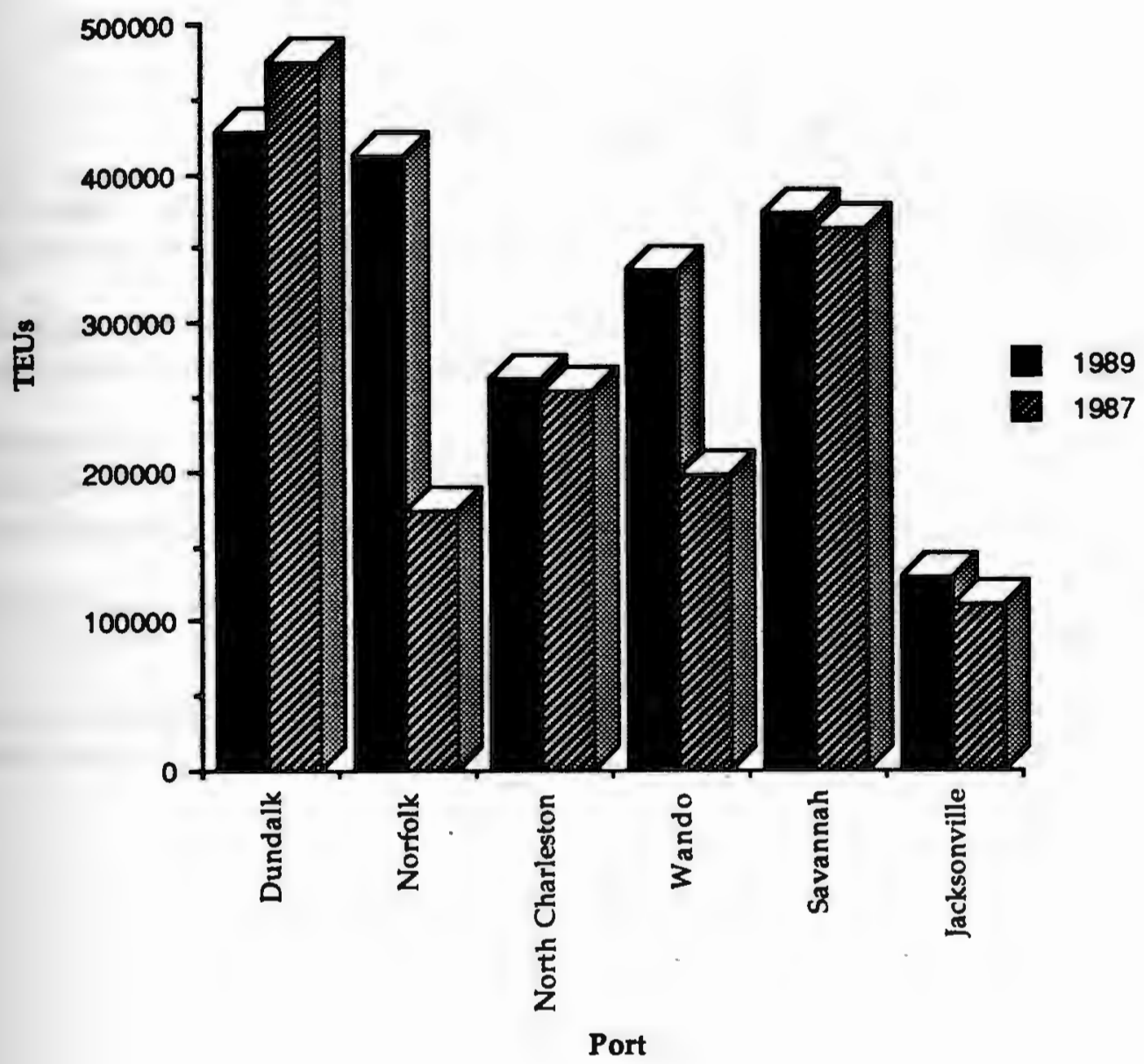

Source: Courtesy of individual ports 
TABLE 5

TEUs BY TERMINAL

1987 TEUs 1988 TEUs 1989 TEUs 1990 TEUs

PORT OF BALTIMORE

Dundalk Marine Terminal

474139

$477093 \quad 427992$

354585

PORT HAMPTON RHODES

Norfolk Inter. Terminal

173057

367006

411177

N/A

PORT OF CHARESTON

North Charleston Terminal

253116

232462 - 261177

N/A

Wando Terminal

197430

226792

333886

N/A

PORT OF SAVANNAH

CONTAINERPORT

362200

365580

372876

402818

PORT OF JACKSONVILLE

Blount Island and Talley.

111046

N/A $\quad 128090$

154491

Source: Courtesy of individual ports 
deregulation, has subsequently intensified the competition among ports for containerized cargo. Not only are ports interested in improving local benefits from their activities, but-as a result of intermodalism-they are concerned with providing connections to as broad an area as possible.

To understand the efficiencies and inefficiencies of competition within the port system, a simple discussion of competition is necessary. If competition fosters better operating efficiency in most if not all industries, then ports are no different on a micro-level than other enterprises. Competition provides fair market prices for the port user without much variation among ports. Although they are governmental entities, ports interact with private international commercial industries. It is in their best interest to keep costs low, so that they can offer competitive service prices for dockage, wharfage, storage and drayage (removal). In this respect, ports are efficient and contribute to the economic well-being of the state and region they serve.

Competition is regarded as offering economic efficiency within an industry. But, there are inefficiencies associated with competition as well. Port expansion is financed through large public expenditures from revenue bonds, reinvested port revenues, and taxes. When substantial port resources are invested in container facilities (superstructure and infrastructure), it is assumed that such investments can be justified. Infrastructure is the physical improvement that allows the vessel to berth at a port. Superstructure is the equipment that is necessary to handle and transport the cargo in the port. Because such facilities take many years to plan and develop, there is a level of uncertainty with respect to future cargo flows which will pass through the new facility. Due to the high level of competition among the transportation industry as a whole, the impetus for new port developments lies in the hope 
for cargo attraction, rather than actual cargo growth at the port. Often then, new port expansion projects cannot be quantitatively justified because new growth in cargo throughput has not occurred. In these cases, underutilized facilities, including large unused portions of facilities beyond those necessary to accommodate peak trade periods, represent inefficient public expenditure as well as inefficient coastal land use.

Inefficient coastal land use may not represent a problem if an alternative use does not exist. Much of the land which has been used for new container facilities, however, is a result of filled wetlands or converted coastal ecosystems. Loss of environmental quality as well as the value associated with use and non-use of the land resource represents a coastal land use problem worth correcting.

In addition, public ports can often acquire coastal lands at a lower cost than improving operating efficiency at existing facilities. Ports often acquire land as part of their charters. They can also acquire tax-free land because they are a public agency. Ports, in effect, have an advantage over all other waterdependant, water-related and non-water related uses. Inefficient land use by ports, therefore, may not affect overall efficiency if more land can be cheaply acquired rather than restructuring existing facilities. This acquisition will not contribute to higher average costs in the port. In these cases it is possible that acquiring more land will be more economically efficient to the port but not necessarily more socially efficient.

Free competition, without regulation, will, like other competitive industries, improve market efficiency on a port level by providing better service, and fair market prices to the port user. However, while efficient for the industry, expanding the supply of the port service market implies social external costs involving the mis-use of public funds and coastal lands. 
Indeed, port competition has intensified along the East Coast, and ports there have demonstrated their continuing desire to place more importance upon container cargo. These increasing levels of competition along with the fact that ports are concentrating more resources on container handling capabilities, suggest that the problems associated with over-supply will increase into the future. In this respect, the competition associated with containerization and the quasi-public port has led to a sub-optimal efficiency condition on the social level. To correct this situation, more information on port growth requirements must be obtained and made available for future planning. 


\section{CHAPTER THREE \\ CAPACITY ANALYSIS AND PRODUCTIVITY}

In order to manage any system effectively, quantitative information is necessary to ensure quality and efficient productivity consistently. Through accurate measurement of productivity and growth, a port can better manage its existing capacity and plan for required expansion. Capacity monitoring can lead to maximum efficiency in port productivity and more efficient coastal land utilization. As publicly owned, non-profit agencies that operate on public land, ports must make efficient use of coastal space to accommodate public interests. The allocation of coastal space for port development excludes others from the use of this space. Social inefficiency occurs if the benefits of land use do not equal or exceed the opportunity cost of the land.

Port development results in environmental degradation associated with dredging and filling (Zabel 0. Tabb, in Kalo, 1990). In addition, vessel traffic contributes to environmental degradation from air and water pollution. This pollution places additional stress on natural ecosystems. Ecosystems can be lost and disturbed by any development activity. But, some waterfront development is necessary in environmentally sensitive areas for water-dependent and water-related uses such as ports. In the proper management of coastal lands, non-water dependant uses such as residential construction should not take precedence over water-dependent port activity. In accordance with proper coastal land management, development should not usually take place in environmentally sensitive coastal areas if it is not 
necessary. Port activity is water-dependant and should not be denied if benefits are shown to exceed costs. The negative consequences associated with port development projects imply that port managers, in cooperation with public officials, should utilize planning techniques designed to limit port overcapacity.

The management of coastal space is becoming increasingly important as the demands on coastal lands increase. Public policy which addresses coastal issues in an integrated fashion is required for the proper preservation and protection of the environment in the future. Since ports require large amounts of coastal space to operate effectively, it is necessary that port requirements be quantified through productivity monitoring and capacity review. In this respect, port development can be justified. If it is justified, port development should be incorporated into integrated mechanisms for the management of the environment and expenditure of public funds.

A container capacity review can provide information to port managers and public authorities about the development needs of a port. Capacity review can also be used to indicate how much excess capacity is justified. Accordingly, "the more productive you are, the more capacity can be generated in your terminals, and the less you need to expand them." (Ashar, 1986, p. 93). Capacity review models, both simple and complex, can be used to determine need for expansion and better productivity.

\section{Measuring Container Productivity and Capacity}

Industry pressures for improved productivity at container facilities has stimulated ports to take a serious look at improving facility productivity. In response to this demand, there has been considerable interest in the manner 
by which container facility productivity can be measured (Dowd and Leschine, 1990). Accurate quantification and monitoring is necessary to assess production at container facilities. This measurement gives ports a better understanding of their capacity needs as well as their productivity strengths and weaknesses. Productivity analysis and monitoring also serves as a valuable planning tool, not only for ports, but for society. It is a means to achieve more efficient coastal land use.

A container facility involves interaction of port users and port facilities. The level of a facility's operations efficiency depends upon the productivity of berths, cranes, container yards, gates and labor. Included below is a sample of how productivity and capacity in container facilities can be measured. These measurements have been outlined and suggested as a result of the National Research Council's 1986 Study addressing the improvement of productivity in U.S. container facilities (National Research Council, 1988).

Productivity Factors Which Affect Container Facility Operations.

The Container Berth represents the focal point of port productivity. The factors which influence berth productivity include its length, the number of cranes, berth occupancy, and cargo movement operations to and from the berth. To measure berth productivity, a manager must take into account the number of container vessels worked per year at a particular berth in addition to the length of the work shift and the number of shifts per year. This factor represents net-berth occupancy or utilization. 
The Container Yard along with the berth are the two most important areas where investment is made. Efficient productivity management, therefore, must be concentrated in these two areas. The factors which influence yard productivity include storage acres, shape of land area, type of storage system (chassis or stacked), container dwell time (the time from when the cargo enters the yard to when it leaves), roadway design and labor productivity. Productivity in the yard is measured by TEUs per year per gross acre, and TEU capacity per net storage acre. Gross acreage includes the entire area, while net-acreage consists of gross acreage minus infrastructure improvements, such as roads, buildings and other areas which have constraints on storage. This measurement yields the productivity factor, yard throughput, and yard storage.

The Crane characteristics, including weight capacity, single or double lift potential, breakdowns and vessel characteristics influence its productivity. Normally, cranes operate at a rate of 20-35 TEUs per hour (Containerization International, 1987). Double lift cranes can achieve 50 lifts per hour (Container News, 1988). However, varying rates are a function of operator skill. Operational delays and downtime also influence overall productivity. Crane productivity is measured by moves per hour, downtime and crane hours. This measurement yields net and gross productivity.

The Gate is an important element of facility productivity. The factors which affect gate productivity include operational hours, number of lanes, extent to which it is automated and whether a data collection system exists. Better productivity in the gate depends largely upon the efficiency of container weighing and documentation checks. Productivity of the gate is 
measured in containers per hour, per lane, and truck turnaround time. These figures yield net and gross throughput factors.

Labor is the final major element affecting facility productivity. Gang sizes, work rules, general skill of workers, work environment, amount of training and vessel characteristics all influence labor productivity. This productivity is measured by the number of moves per man hour.

Many factors within the operating port affect capacity. From an operations standpoint, productivity among the various sectors in the port influence and determine overall productivity and available capacity. In this thesis, physical productivity measures of capacity are calculated, not cost efficiencies. According to some models, optimal capacity has been determined using costs and financial efficiency (Varaprasad, 1986). Due to the fact that the above cost methods do not include the social cost of overcapacity, they may not be accurate. In addition, this study examines physical overcapacity as a social inefficiency. Thus, it is concerned only with physical productivity measures.

The following analysis attempts to demonstrate two things. First, it determines whether the seven container facilities studied exhibit individual overcapacity. It has been suggested that, "U.S. public ports have failed to enhance productive usage of container facilities" (Ashar, 1986). The capacity analysis demonstrates whether this is true or not. Second, the analysis serves to demonstrate the usefulness of accurate productivity data as a tool to monitor port capacity at container facilities. The quantification of capacity is an important step toward the prevention of unnecessary port investment. In addition, through productivity monitoring within the port, quality control 
can be better maintained, and improvements in these productivity measures can more easily be attained.

\section{Method}

The method that will be used to test the major hypothesis is based on a capacity modeling formula called The Container Capacity Model that has been previously utilized by the Ports and Inland Waterways Institute. It is an input/output model in which the input variables include productivity ratios for the storage yard and berth utilization. For example, data on berth utilization (i.e. number of vessel calls, typical number of containers per call and ship-shifts worked per vessel) will be divided by the total number of vessel shifts in a year to yield the berth requirement for a given number of vessels and containers.

These variables are a function of variable shipping line characteristics per port, including size of vessels and frequency of calls. In addition, typical loading, unloading, and storage ratios are added to accurately account for cargo handling operations within ports.

The Container Terminal Capacity Model was developed as a practical planning tool and was originally used at the Port of Seattle to assess container facility capacity (Ashar, 1986). In the absence of true cost figures, cargo movement productivities are utilized to accurately assess facility efficiencies. Limitations of the model, however, are that the ratios used for facility operations assume equal operational efficiencies among facilities with regard to cargo movements per hour and per vessel. Although these ratios do not yield exact results for a particular facility, they are based upon reasonable 
industry data and will yield reasonably accurate output information (Ashar, 1986).

Based upon shipping line characteristics, actual berth utilization, and container yard productivity data, the model permits an accurate measurement of container capacity at a facility. Once the capacity is evaluated, the amount of excess can be determined by simply comparing capacity with actual cargo throughput.

\section{Berth capacity}

Berth capacity is a function of crane productivity, and labor productivity per ship size and shipping line class (See Table 6). To simplify the model, ship sizes were categorized into three classes:

Large Lines-call every seven days or less, exchange 1,000 or more boxes per call, and contribute 100,000 TEUs per year.

Medium Lines--call every seven to ten days, exchange 600 boxes per call and contribute 50,000 TEỤs per year.

Small Lines- -call 15 or more days, exchange 100-200 boxes per call and contribute 5 to 10,000 TEUs per year.(Ashar, 1986)

Individual vessels may be considered in berth capacity calculation, unfortunately, necessary size information was not available for this study.

Typically, container berths can move an average of 170 boxes per crane shift (Ashar, 1986). Of course, this number varies with the number of cranes per berth and the skill of the crane operator. A shift is considered to entail an eight hour time period. Ship size affects unloading or loading requirements. 
TABLE 6

\section{BERTH CAPACITY CALCULATION}

\begin{tabular}{|c|c|c|c|c|c|}
\hline Line Type & Movedcall & $\begin{array}{c}\text { Movea/crane } \\
\text { chift }\end{array}$ & $\begin{array}{c}\text { Average Shift } \\
\text { per all }\end{array}$ & RHL & RHU Average \\
\hline Large & 1500 & 170 & 8.82 & 12 & 1.36 \\
\hline Medium & 600 & 150 & 4 & 6 & 1.5 \\
\hline Small & 200 & 120 & 1.67 & 3 & 1.8 \\
\hline $\begin{array}{l}\text { Net shifts } \\
\text { per call }\end{array}$ & Safety Margin & Shiftetyear & $\begin{array}{c}\text { Berth } \\
\text { Requirement }\end{array}$ & & \\
\hline 7 & 6 & 678 & 0.64 & & \\
\hline 4 & 6 & 521 & 0.49 & & \\
\hline 2 & 6 & 146 & 0.14 & & \\
\hline
\end{tabular}

Average Berth Requirement Per Ship Line= .23

Source: Ashar, 1986 
Thus, large ships require more shifts. Subsequently, the berth requirement for larger vessels is greater.

The operational factors added in the calculation of the berth requirement coefficient reflect productivity margins. The Reasonably High Level Factor (RHL) accounts for high ship loads and/or low productivity on the berth. The safety margin accounts for the margin of time between ship arrivals to assure that no ships have to wait. Finally, the berth requirement was obtained by dividing gross ship shifts per year by the total shifts in a year.

Yard capacity

A conservative assumption of 50 acres required per berth was made to accommodate the varying degrees of yard utilization among the ports in this study. This acreage is deemed sufficient to permit the effective operation all types of yard systems.

Based upon accurate shipping line characteristics at the facility, and given yard acre requirements per berth, capacity of the port can be generated. Further, berth and yard requirements are indicated. The amount of excess capacity can be determined.by comparing these three results to actual cargo and physical characteristics.

\section{Calculations}

The calculations for the total container capacity within a given facility is measured in TEUs or container units. Total capacity includes empty as well as full containers. It should be noted that the final capacity number for a facility included the characteristics of shipping lines, operations on the berth 
and in the yard, and other port operations. The individual facility analyses proceeded according to the numbered steps which follow.

\section{Average berth requirement}

The average berth requirement was calculated based upon the shipping characteristics outlined previously. Table 6 p.58, summarizes the berth requirements for each line type. Data needed to make exact calculations were not available from the ports, therefore, an average requirement was determined based upon Table 6. The average berth requirement for a model ship line generating an average of 52,500 TEUs annually is .423 berthing space.

\section{Determining the number of model ship lines per port}

To determine the berth requirement for actual cargo throughput, the average berth requirement for a ship line generating 52,500 TEUs must be multiplied by the representative number of model lines. This is not the actual number of lines in the port. It is, however, representative of many lines exhibiting similar size and cargo generation characteristics. For example, rather than counting ten ship lines, one line is used to account for the requirements of all ten actual lines. The following demonstrates the line calculation:

Total \# of TEUs per year / 52,500 TEUs = \# of Model lines.

\section{Determining total berth requirement}

The total berth requirement is the necessary amount of berth space needed to accommodate existing cargo throughput and is determined by the following:

*of Model Lines * .423 = Total Berth Requirement. 
This calculation is useful to the port in order to determine whether sufficient berth space is available for existing cargo throughputs. As a planning tool, berth capacity calculations can be used to indicate whether or not additional berths will be required. In addition, if sufficient excess is shown using this calculation, a particular port can formulate investment criteria based, in part upon berth requirements.

\section{Determining yard requirement}

Earlier, it was stated that yard moving systems vary considerably. A standard yard requirement does not give justice to the effectiveness of a particular yard system. Because different yard systems yield different yard productivities, this study assumes a conservatively high yard requirement. Normally, 30 to 50 acres of yard storage space is needed per berth (Hershman, 1989). For the subsequent analysis, 50 acres will represent the storage space required per berth.

\section{Highest attainable berth productivity}

A number of factors influence the productivity in berths, as mentioned earlier. High levels of productivity are 150,000 TEUs/berth/year (Gilman, 1987). But, because all ports have different physical and operational characteristics, setting a single high industry standard for all ports is not practical. While berth productivity may be limited to operational barriers, these productivities could be improved in many instances. Although yard moving systems vary, much of the overall superstructure and infrastructure are identical among ports. It is therefore reasonable to assume that a port exhibiting low productivity could make changes enabling it to achieve productivities equal to its neighbor. The use of productivity monitoring is 
justified under this assumption. When capacity can be improved through facility redevelopment unnecessary expansion can be prevented. In this respect, better productivities can increase cargo capacity without significant expansion of land.

Cargo throughput among the ports studied have revealed that the Wando Terminal at the Port of Charleston yields the highest berth productivity at 111,295 TEUs/berth/year. Recognizing the intense competition among these ports, it is not unreasonable to suggest that all ports in the range could achieve this type of productivity figure, given size and facility similarities. It has been demonstrated that ports achieve better productivities than this (Containerization International Yearbook, 1989). Therefore, 111,295 TEUs/berth/year is not extraordinary. This number represents the highest attainable regional berth productivity and is used to calculate the total capacity of the existing port facility. This study indicates that there is sufficient excess in existing facilities to accommodate a substantial increase in cargo throughput. Capacity potentials were calculated according to the following:

Potential throughput given productivity increase = \# of existing berths *111,295 TEUs

* of model lines after productivity increase $=$ Potential Throughput / 52,500 TEUs

Berth requirement for potential cargo increase = \# of Model lines post increase * .423 Yard requirement for potential productivity increase = New Berth Requirement * 50 acres 
The requirements for potential increase represent the total capacity in the port. The excess capacity is simply the difference between utilized capacity and the total port capacity. Applied consistently throughout the range, the calculations represent reasonably accurate capacity assessment. The excess within these ports is not necessarily alarming in itself for most of the facilities studied. What is of concern from a social point of view is that, despite the excess and relatively slow cargo growth trends, these ports continue developing new and improved facilities. Based on these results, such development in many cases may not be justified; for this reason, overcapacity is a public concern.

\section{The Port of Baltimore (Dundalk Marine Terminal)}

In 1706, the Maryland General Assembly established the Port of Baltimore along the Patapsco River. It serves as one of the nation's busiest deep water ports and accommodates all types of cargo in many facilities along a 45 mile shoreline.

The 570 acre Dundalk multi-use Marine Terminal is the largest facility in the port. Dundalk handled the largest share of container cargo throughout the study region in 1989 (Table 5, p. 47). With six berths and ten container cranes, the facility handled approximately 427,000 TEUs in 1989. Despite this apparent success, container throughputs since 1985 have shown a combined decline of about 19 percent (Table 3, p. 40). While this decline continues, there is increasing expenditure on facility improvements within Dundalk Terminal. In 1989, a $\$ 50$ million redevelopment plan was approved to attempt improvement of facility productivity through channel dredging. The improvements are designed to accommodate larger vessels. 
The expenditure of funds for the facility occurs at a time when the port has recently opened its new high technology Seagirt container facility, which is adjacent to Dundalk. Since Seagirt began operations in 1990, its throughputs are excluded from this capacity study. However, the $\$ 280$ million facility was designed to increase total port capacity by 2.5 million tons (The Port of Baltimore 1989 Annual Report). Seagirt certainly will not achieve this capacity in the near future. It therefore represents short-term overcapacity.

While exhibiting negative container cargo growth and recently opening the $\$ 280$ million mega-facility on 114 acres of dredged fill, can the Port of Baltimore justify the proposed redevelopment of the Dundalk Facility? Perhaps, the following capacity analysis could be used to answer this question.

Results of the capacity calculations here reveal that with existing cargo throughputs, approximately 3.5 berths are required with a yard requirement of 173 acres for container storage. Currently, Dundalk operates six berths and 285 acres of yard storage. Given the berth productivity increase of 111,295 TEUs, the potential throughput represents the highest attainable productivity. This potential is not constrained by land or berth space and is possible given existing facility dimensions. The current excess in the Dundalk facility is demonstrated within Table 7 and Figure 8. The validity of this capacity is reinforced by historical cargo throughputs. In 1985, Dundalk was at capacity operating levels when cargo approached 700,000 TEUs.

At 56 percent, the excess in Dundalk is not of major concern on a state or regional policy level. Due to fluctuating market conditions, this capacity may be desirable. But, the adjacent Seagirt facility can handle up to 2.5 million tons of container cargo. Most of this cargo has yet to be seen or 


\title{
CAPACITY CALCULATION FOR DUNDALK MARINE TERMINAL (PORT OF BALTIMORE)
}

EXISTING FACILITIES:

\author{
Land Use
}

$\begin{array}{cccccc}\text { BERTHS } & \text { YARD ACRES } & \text { 1989 TEU } & \text { TEU RANK } & \begin{array}{c}\text { Efficiency } \\ \text { TEUs/Acre }\end{array} & \text { Rank } \\ 6 & 285 & 427992 & 1 & 1502 & 3\end{array}$

4) TOTAL CAPACITY 667,770 TEUs

Average Berth Requirement $=.423$

Average TEUs per Line $=52,500$

1) \# of Model Ship Lines=8.15; 427,992 TEUs /52500 TEUs

2) Total Berth Requirement $=3.45$ berths; 8.15 lines 4.423

3) Yard Requirement = 173 Acres; 3.45 berths *50 acres

4) Potential Throughput

6 berths * 111,295 TEUs/berth/year $=667,770$ TEUs/year

5) \# of Lines After Potential Increase

667,770 TEUs $/ 52,500$ TEUs $=12.7$ Model lines

6) Berth Requirement for Potential Increase

12.7 lines * $.423=5.4$ berths

7) Yard Requirement for Potential Increase

5.4 berths $* 50$ acres $=269$

Source: Port of Baltimore and author's calculations 


\section{FIGURE 8}

1989

\section{DUNDALK MARINE TERMINAL EXCESS}

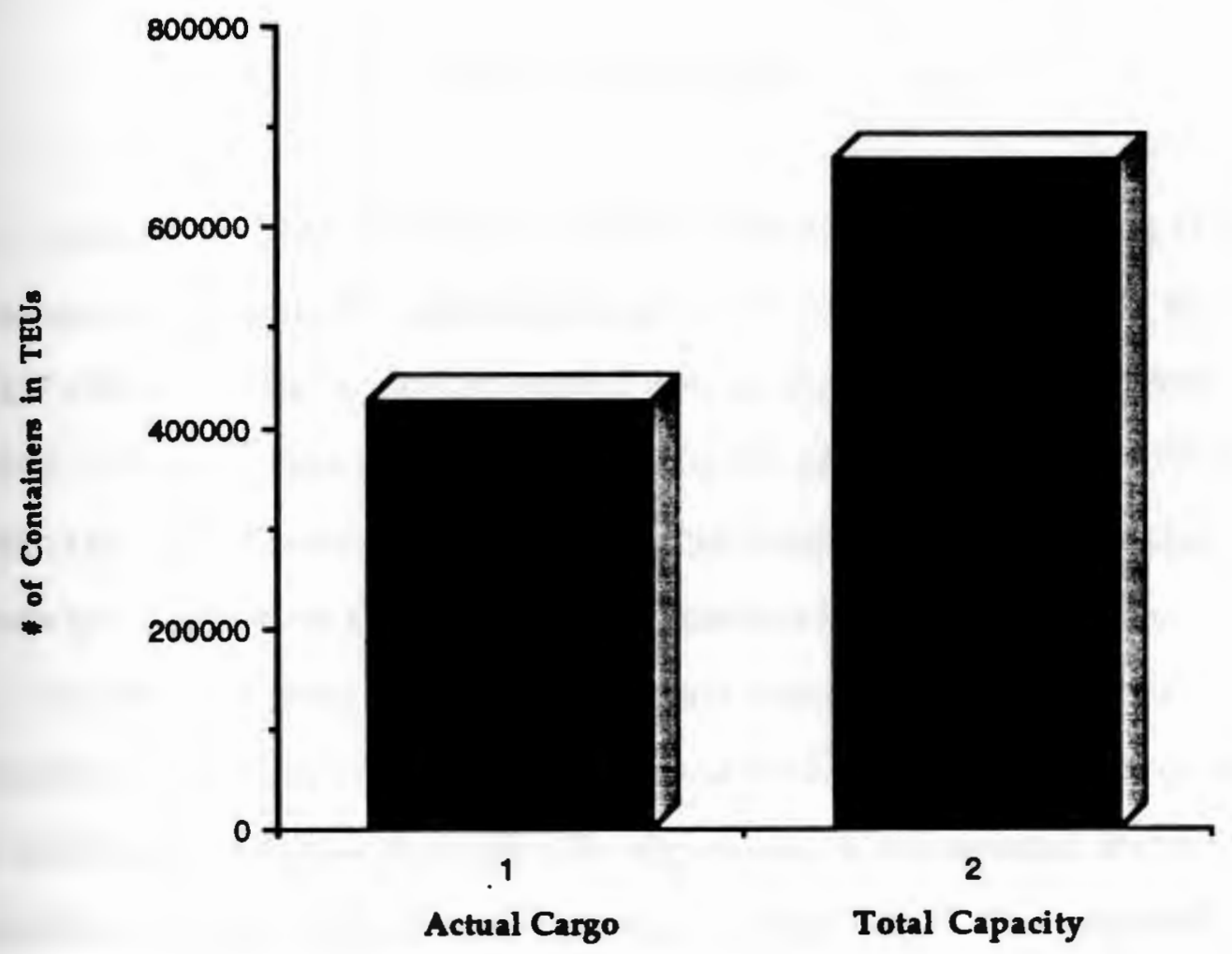

Source: Author's calculations 
committed. The enormous capacity potential between Dundalk and Seagirt is largely under-utilized and does represent a public concern. Even with a 56 percent productivity boost, existing facilities would be able to handle cargo increases. These results demonstrate the possibility that further significant development in the port represents unnecessary over-investment and social cost.

\section{The Port of Norfolk}

Located in Norfolk Virginia, Norfolk International Terminals (NIT) represents an example of successful state port management. In 1989 with 427,177 TEUs, the port is ranked second among the the other large ports studied. Hampton Roads, of which Norfolk is a part, has shown a five year growth rate of 128 percent. Norfolk has contributed significantly to this growth as it represents 60 percent of the business in Hampton Roads.

In 1981, the ports in Virginia imposed integrated management on themselves. Facilities combined their resources and eliminated duplication and inefficiency. Rather than plan for expansion in a disjointed fashion, productivity improvements were made on a broad level. The Neptune computer system was developed in 1986 and provided shippers, agents and other port users with shared data. This cooperation helped to improve operating efficiencies and cargo movements.

Another productivity improvement made in Norfolk was the acquisition of double-hoist container cranes. Double-hoist capability allows crane productivity to be improved from 25 lifts per hour to 50 lifts per hour (Container News, 1988). These improvements, which are regarded as innovative, contribute greatly to the success of Norfolk. 
Another innovation was the development of the Virginia Inland Port (VIP). The port serves as a cargo storage and intermodal transfer facility between trucks and rail cars. Located inland from the port, it allows better positioning of cargo destined for and from Midwest locations. VIP has a direct rail link to Norfolk and allows for more storage capability without additional coastal development. By developing VIP, Virginia has facilitated inland cargo transfer, reduced stress on existing coastal capacity, bypassed additional coastal land use, and saved expense with inland as opposed to coastal development. All of these factors contribute to success in land use and in the prevention of wasteful excess.

Growth in Norfolk is planned on 11 acres of wetlands on the north end of the facility. A mitigation plan has been approved by the Army Corps of Engineers for this development. The results of capacity review indicate that, with a five-year 128 percent growth rate, this expansion can be justified. By incorporating capacity analysis with environmental considerations, permitting agencies, such as the Army Corps of Engineers, can better satisfy the criteria of permits required for dredge and fill activities under section 401 of the Clean Water Act. Capacity analysis can indicate the need for development, which satisfies requirements of the permit (See Table 8 and Figure 9).

\section{Port of Charleston (North Charleston Terminal)}

The North Charleston Terminal is located 90 minutes from the mouth of Charleston Harbor on the Cooper River. North Charleston handled 261,177 TEUs in 1989 ranking fifth among the seven facilities studied. With three container berths and 185 yards for container storage, the facility has a 


\section{TABLE 8}

\section{CAPACITY CALCUATION FOR THE PORT OF NORFOLK}

EXISTING FACILITIES:

BERTHS YARD ACRES

4

479
LAND USE

EFFICIENCY

1989 TEU.

TEU RANK

TEU\&/ACRE

858
RANK

5

4) TOTAL CAPACITY 445,180 TEUS

Average Berth Requirement $=.423$

Average TEUs per Line $=52500 \mathrm{TEUs}$

1) \# of Model Ship Lines = 7.83;

411,177 TEU/ 52,500 TEUs

2) Total Berth Requirement $=3.3$ Berths

7.83 lines" .423

3) Yard Requirement $=166$ Acres

3.3 berths ${ }^{4} 50$ acres

4) Potential Throughput $=445,180$ TEUs

4 berths * 111,295 TEUs/berth/year

5) \# of Lines After Potential Increase $=8.48$ Model lines

445,180 TEUs / 52,500 TEUs

6) Berth Requirement for Potential Increase $=3.6$ berths

8.48 Model lines* .432

7) Yard Requirement for Potential lncrease $=179$ acres

Source: Port of Norfolk and author's calculations 


\section{FIGURE 9}

1989

\section{NORFOLK TERMINAL EXCESS}

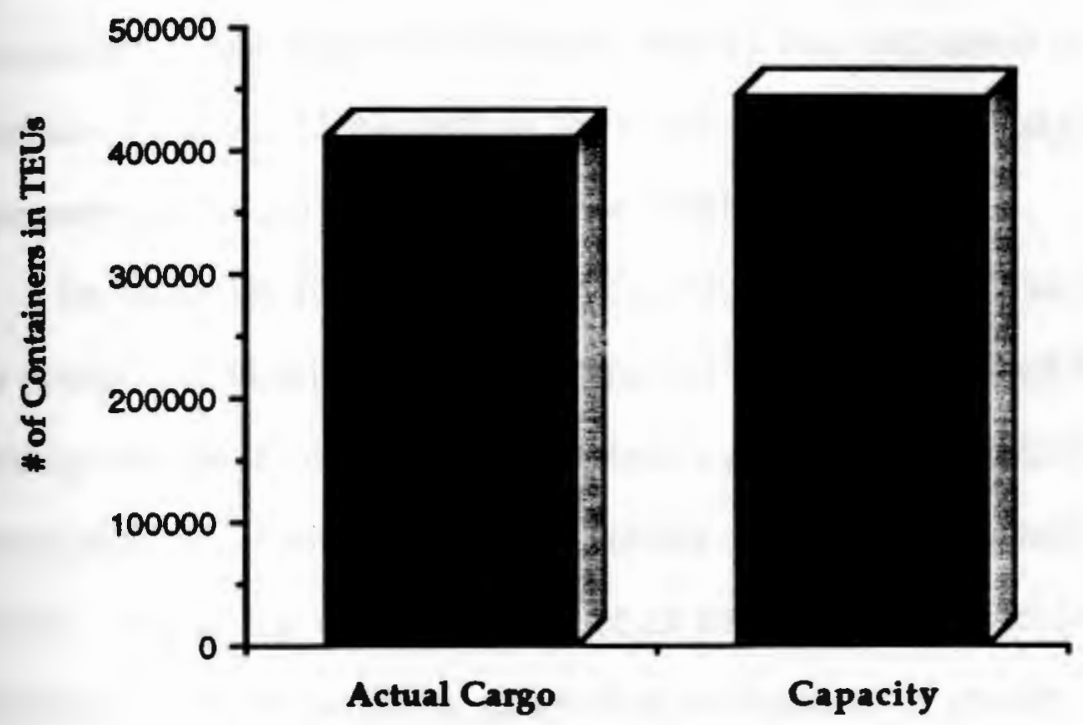

Source: Author's calculations 
total existing capacity of 333,886 TEUs per year. This capacity requires 2.10 berths and 105 acres of back-up storage. These figures indicate excess capacity of about 28 percent. Even with potential increases realized, existing infrastructure is sufficient to handle new cargo throughputs (See Table 9 and Figure 10).

Development plans in North Charleston include two additional berths for container cargo and other cargo types. Historic container growth demonstrates that North Charleston facility has increased its share of regional container cargo to 13 percent of the market in 1989 with signs of continuing improvement in the early 1990s. (See Table 3, p. 40).

Its land use efficiency ranks fourth overall, which is relatively efficient. The acceptable efficiency, typical amount of excess, limited future development and continuing container cargo growth indicate that overcapacity may not be a social concern at the North Charleston container facility. Due to the multi-use nature of the facility, the additional berths to be developed may be justified, given the indications of growth in the facility.

\section{Port of Charleston (Wando Terminal)}

The Wando Terminal is located one hour from Charleston Harbor on the Wando River. Its three developed berths handle more cargo per berth than any of the other six container facilities. The modern practices and location of this facility result in a highly efficient container facility.

The Wando Terminal represents the highest productivity among the ports studied. This productivity is based upon the Number of TEUs handled per acre and per berth. It is a conservative standard for all facilities in the region. As competitive ports with similar practices and facilities, it is 


\section{TABLE 9}

\section{CAPACITY CALCULATION FOR THE NORTH CHARLESTON TERMINAL (PORT OF CHARLESTON)}

EXISTING FACILITIES:

BERTHS YARD ACRES

3

192
1989 TEU。

261177
LAND USE EFFICIENCY TEUs/ACRE

1360
RANK

5

Average Berth Requirement $=.423$

Average TEUs per Line $=52,500$ TEUs

1) $\#$ of Model Ship Lines $=4.975$

261177 TEUs / 52,500 TEUs

2) Total Berth Requirement $=2.10$ berths

4.975 Model Lines* 423

3) Yard Requirement $=105$ acres

2.10 berths * 50 acres

4) Potential Throughput $=333,886$ TEUs

3 berths * 111295 TEUs/berth/year

5) \# of Lines After Potential Increase $=6.36 \mathrm{Model}$ Lines 333,886 TEUs/ 52,500 TEUs

6) Berth Requirement for Potential Increase $=2.69$ berths 6.36 lines" .423

7) Yard Requirement after Potential Increase $=135$ acres 2.69 berths * 50 acres

Source: Port of Charleston and author's calculations 


\section{FIGURE 10}

1989

\section{NORTH CHARLESTON EXCESS}

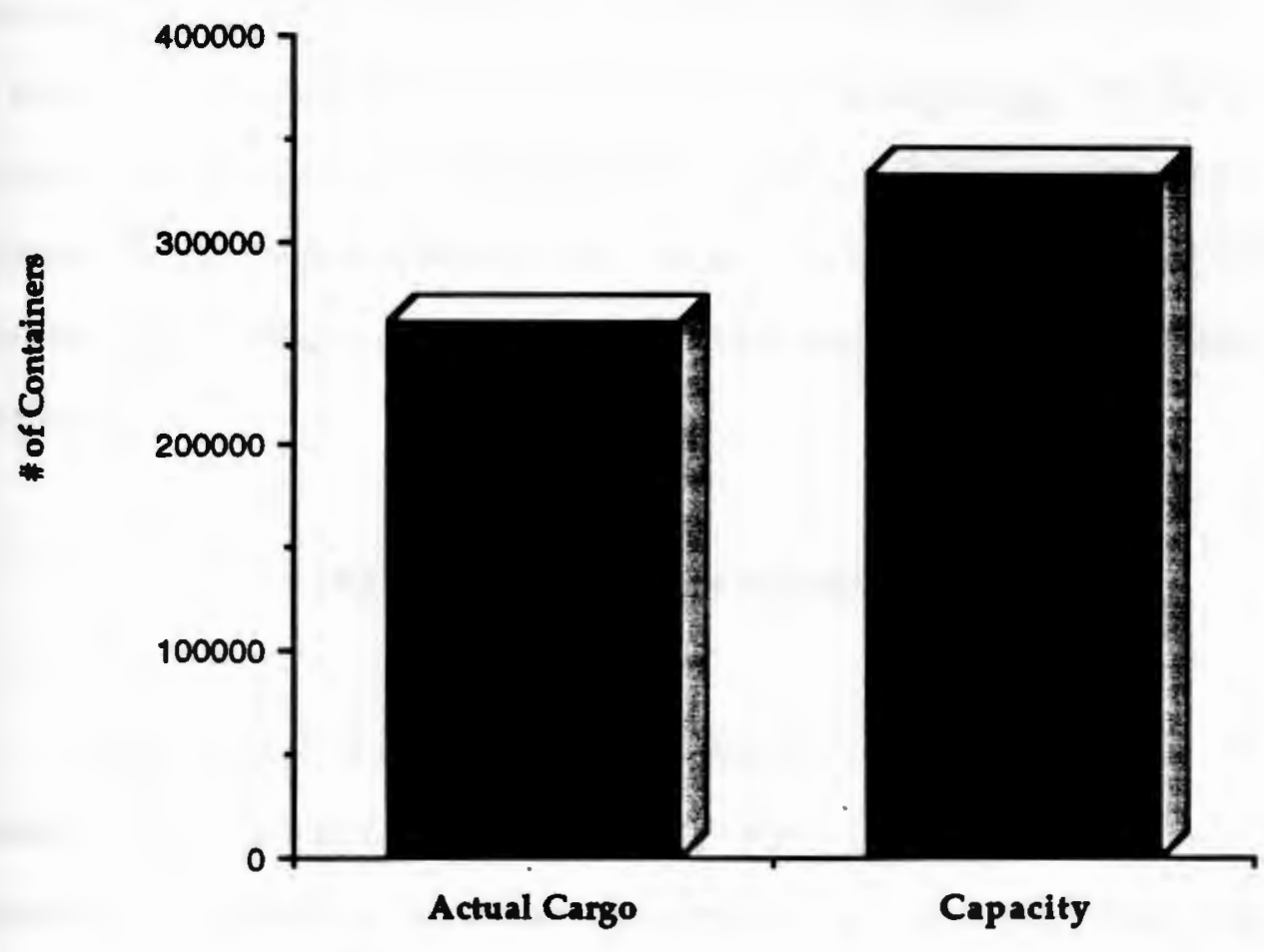

Source: Author's calculations 
assumed that all of the ports could be as productive per berth as the most productive competitor.

The Wando standard is conservative because it does not exhibit extra ordinary productivity for a container port and it does not hold an advantage in total cargo handled compared to the other ports. In fact, Wando is ranked fourth in total container cargo handled. Because it is the benchmark facility, it is assumed that there is no overcapacity at Wando (See Table 10). Although there may be excess in the facility, for the purposes of this analysis, it will not be a factor. As the most productive port in the study range, Wando represents the most efficient facility that society can obtain at this time. In other words, while there may be some additional excess at Wando, the perfectly efficient container facility does not exist and so Wando represents the next best alternative.

\section{The Port of Savannah (Containerport)}

Containerport is located on the Savannah River, northwest of Savannah. The 245-acre container facility captured almost 20 percent of the regional market share and ranked third overall in total container cargo. Similarly, Containerport's land use efficiency ranked second .

Total capacity was 556,475 TEUs, and in 1989 , the facility handled 372,876 TEUs. This represents a total excess of 49 percent. The facility currently operates five berths with 245 acres of container storage. Berth requirements for its potential cargo increase are 4.5 with a yard requirement of 224 acres (See Table 11 and Figure 11). 


\section{CAPACITY CALCULATION FOR THE WANDO TERMINAL (PORT OF CHARLESTON)}

EXISTING FACILITIES:

BERTHS YARD ACRES

3

150

$\begin{array}{cc}1969 \text { TEUs } & \text { TEU RANK } \\ 333886 & 4\end{array}$

LAND USE

EFFICIENCY TEUs/ ACRE

2226
RANK

1

Average Berth Requirement $=.423$

Average TEUs per Line $=52,500$ TEUs

1) \# of Model Ship Lines $=6.36$ Lines

333,886 TEUs / 52,500 TEUs

2) Total Berth Requirement $=2.69$ Berths

6.36 Lines ${ }^{*} .423$

3) Yard Requirement $=135$ acres

2.69 berths $* 50$ acres

Source: Port of Charleston and author's calculations 


\section{CAPACITY CALCULATION FOR CONTAINERPORT (PORT OF SAVANNAH)}

EXISTING FACILITIES:

BERTHS YARD ACRES $1989 \mathrm{TEU}$ 5 245 372876 3

1522

LAND USE EFFICIENCY TEU\&/ ACRE

RANK 2

\section{TOTAL CAPACITY 556,475 TEUs}

Average Berth Requirement $=.423$

Average TEUs per Line $=52,500$ TEUs

1) \# of Model Ship Lines $=7.10$

372,876 TEUs / 52,500 TEUs

2) Total Berth Requirement $=3$ berths 7.10 Model lines * .23

3) Yard Requirement $=150$ acres

$$
3 \text { berths * } 50 \text { acres }
$$

4) Potential Throughput $=556,475$ TEUs

5 berths * 111295 TEUs

5) \# of Lines After Potential Increase $=10.6$ Model Lines

556,475 TEUs/52,500 TEUs

6) Berth Requirement for Potential Increase $=4.5$ berths 10.6 Lines* .423

7) Yard Requirement after Potential Increase $=224$ acres 4.5 berths " 50 acres

Source: Port of Savannah and author's calculations 


\section{FIGURE 11}

1989

\section{PORT OF SAVANNAH (CONTAINERPORT) EXCESS}

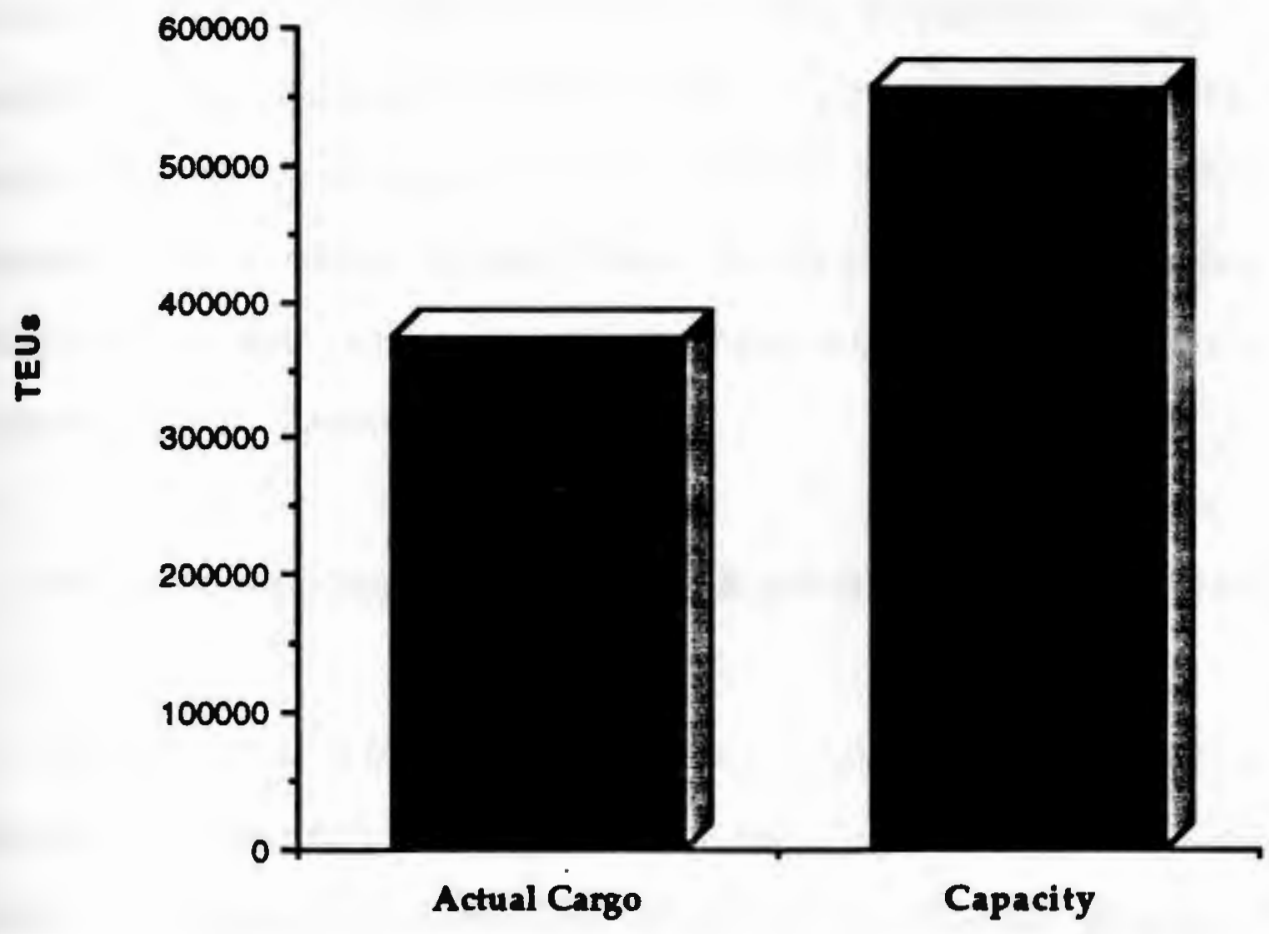

Source: Author's calculations 
Containerport has shown continuing growth in the 1980s with an eight percent cargo increase from 1989 to 1990 (Table 3, p. 40). The excess in the facility does suggest that Containerport is not in need of future expansions for container cargo. Despite its excess, developments planned for Containerport include the addition of a sixth berth plus 42 acres of storage space at the ocean city facility, which is where Containerport is located. As a multi-use facility that handles break-bulk and bulk in addition to container cargoes, the development of one extra berth may be justified to handle all cargo efficiently. In addition, total container capacity may be slightly overstated in the analysis due to the multi-use nature of the facility. Therefore, 49 percent excess is not alarming in this facility. Further, the exhibited growth and efficiency of the facility indicate that problematic overcapacity may not be evident at Containerport in Savannah.

The Port of Jacksonville (Talleyrand and Blount Island Terminals)

The Talleyrand Marine Terminal is a multi-use facility located twentyone miles from the Atlantic Ocean on the St. Johns River. It is a 156 acre facility that handles containers, bulk, autos, and break-bulk cargoes. The Blount Island Terminal is nine miles from the Atlantic Ocean and includes 870 total acres of port facilities. Due to the relatively small amount of container cargo handled in both Blount Island and Talleyrand, these facilities were combined as a single unit operated by the Port of Jacksonville for the purposes of this study. The excess shown in Jaxport may reflect some loss of efficiency in container operations as a result of two separate facilities that are fairly close in distance. 
The combined number of containers in $\mathbf{1 9 8 9}$ for the Blount Island and Talleyrand Terminals was 128,090 TEUs. This gave Jaxport a 6.62 percent share of the regional market. Container facilities within the port included eight total berths with 228 yards of container storage.

The calculated capacity in Jaxport is 565,957 TEUs annually. Excess capacity, therefore, is shown to be 77 percent. It should be noted that the proved excess in this study does not consider how container storage is used by other cargoes in a multi-use facility. This limited perspective may, therefore, overstate total excess. Nevertheless, a proved excess capacity with regard to container cargo to some degree exists (See Table 12 and Figure 12).

Container cargo is continuing to increase within the port at a proven rate of 56 percent from 1989 to 1990 (See Table 3, p. 40). Development within the port involves the acquisition of three new cranes and some restructuring within the facility. Because the port has a competitive disadvantage among its competitors, such as Norfolk and Savannah, Jaxport has continued to focus on other types of cargoes. The specialization in autos, bulk and breakbulk cargoes has given Jaxport success in these areas of trade. Although exhibiting a large degree of overcapacity with regard to container cargo, Jaxport has attempted to utilize its land by pulling resources away from containers and moving them toward other cargo operations and marketing. Although demonstrating some success in other areas of trade, there exists a large degree of overcapacity within the port that is not necessary for the purposes of trade activity. 


\section{CAPACITY CALCULATION FOR BLOUNT ISLAND AND TALLEYRAND TERMINALS (PORT OF JACKSONVILLE)}

EXISTING FACILITIES:

BERTHS YARD ACRES

8

228

\author{
128090
}

LAND USE EFFICIENCY TEUa/ ACRE

562
RANK

6

Average Berth Requirement $=.423$

Average TEUs per Line $=52,500$ TEUs

1) \# of Model Ship Lines = 2.44 Lines 128,090 TEUs / 52,500 TEUs

2) Total Berth Requirement $=1.03$ Berths 2.44 Lines * $\$ 23$

3) Yard Requirement $=52$ acres

1.03 berths * 50 acres

4) Potential Throughput $=565,957$ TEUs

5 berths * 111,295 TEUs/berth/year

5) \# of Lines after Potential Increase $=16.96$ Lines

565,957 TEUs $/ 52,500$ TEUs

6) Berth Requirement for Potential Increase $=\mathbf{4 . 6}$ berths 10.78 Lines * .223

7) Yard Requirement after potential Increase $=228$ 4.6 berths * 50 acres

Source: Port of Jacksonville and author's calculations 


\section{FIGURE 12}

1989

\section{PORT OF JACKSONVILLE EXCESS}

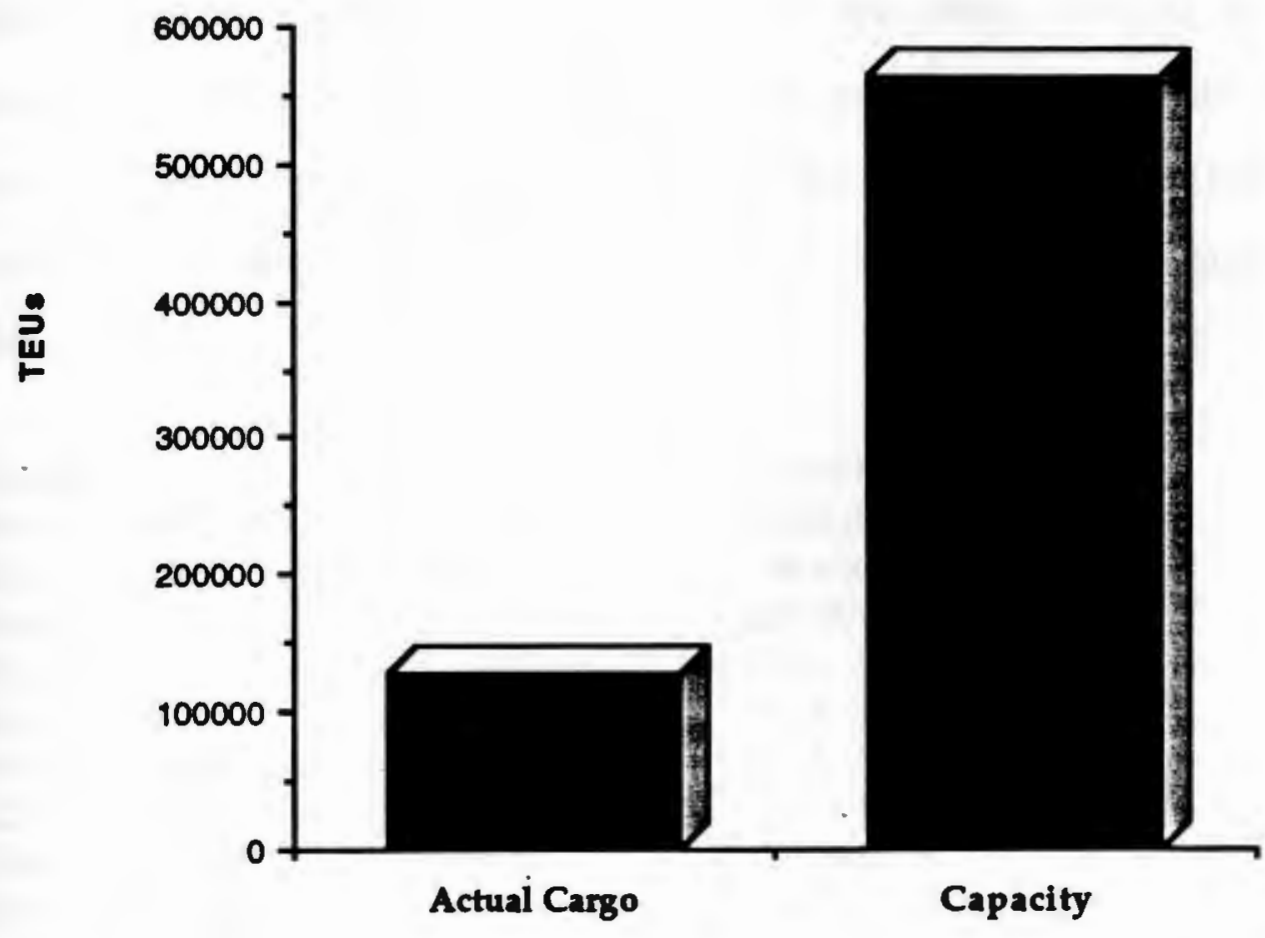

Source: Author's calculations 


\section{OTHER PORTS}

The 33 percent excess capacity among the seven container facilities in this study demonstrates a certain degree of overcapacity. This figure in itself is alarming given that average growth for container cargo in ports is eight percent (American Association of Port Authorities, 1990). Despite the excess ports continue to develop. In addition, there are at least ten smaller container facilities throughout the mid and south-Atlantic port range. The following identifies these ports and lists their respective container throughputs in TEUs.

Chester

Fernandina, El

Gloucester City

Miami

Palm Beach

Philadelphia

Port Everglades

Richmond, VA

Wilmington, DE

Wilmington.NC

Total
32,286

35,818

68,450

337,961

121,137

80,674

235,865

26,001

78,284

99,031

\section{1,115,506 TEUs}

Excluding these ten smaller ports, the seven large facilities that were studied have an excess of almost 1 million TEUs annual throughput. Therefore, the seven large ports as they exist today, could handle the combined cargo from the ten smaller ports. Here, significant overcapacity can be seen. 
These figures raise some interesting policy questions regarding how to react to such over-supply. One approach could be to only distribute federal dredging funds to those ports which are successful. However, the commerce clause in the United States Constitution prohibits favoritism toward any one port. In fact, this is one of the major arguments against federal port control. An alternative approach is to tighten controls on development. The problem with development control is that no direct control mechanism now exists. Permit denials are based only upon environmental considerations and do not include the actual capacity needs of a port. Permit denials which neglect technical information on capacity needs can harm a port's ability to compete. A summary of the existing U.S. system shows that 131 public autonomous ports are competing against each other, which has resulted in vast overcapacity of container facilities without any federal mechanism to directly control the public waste of this over-supply (Welch,1991).

Throughout the previous discussions presented in this thesis, it has been suggested that a mandatory capacity and productivity analysis must be carried out by ports in conjunction with MARAD and used during permit review to fulfill the requirements of Sec 401 permits, as outlined by EPA and the Army Corps of Engineers. Such an analysis can provide all the necessary information to port management and regulators so that proper planning and development can occur on a broad level.

A comprehensive review could help prevent overcapacity without involving excessive federal control that may hamper a port's ability to compete. The need for measurement and analysis has been supported by the evidence shown of existing excess capacity along the mid-Atlantic port range, and by the proof of the increasing amount of development occurring despite the current excess. The need for capacity review is especially reinforced when 
observing the added capacity excess of the many smaller container facilities outlined above.

Figures 13 and 14 summarize the findings of the previous analysis. It is shown that total container handling capacity within the ports studied is approximately three million TEUs while actual cargo throughputs are approximately only two million TEUs. A 33 percent excess indicates that there is overcapacity at the facilities studied in the mid-Atlantic port region, individually and collectively. 


\section{FIGURE 13}

\section{TOTAL EXCESS CAPACITY THROUGHOUT STUDY RANGE (1989)}

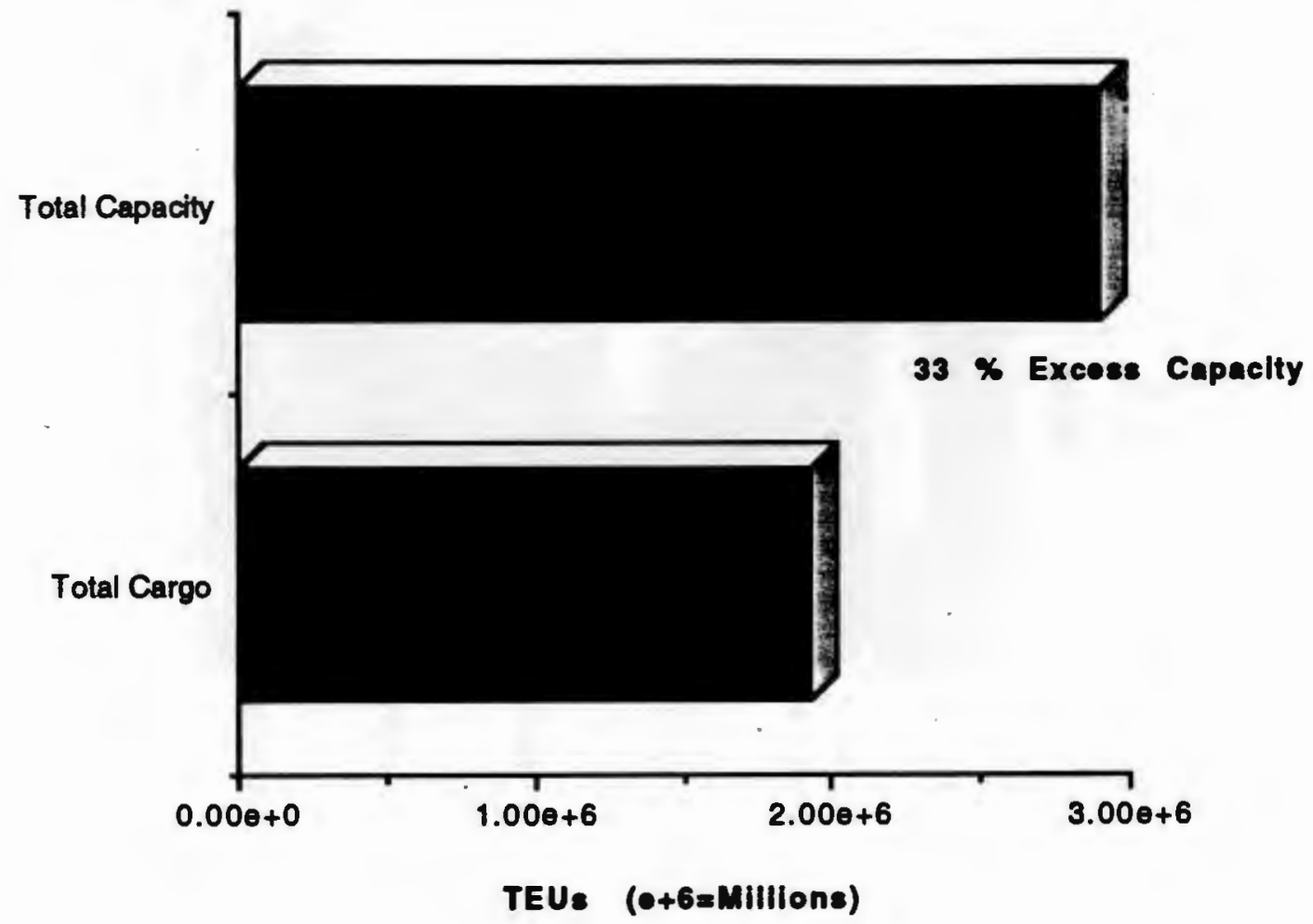

Source: Author's calculations 


\section{FIGURE 14}

\section{ACTUAL CARGO v. CAPACITY}

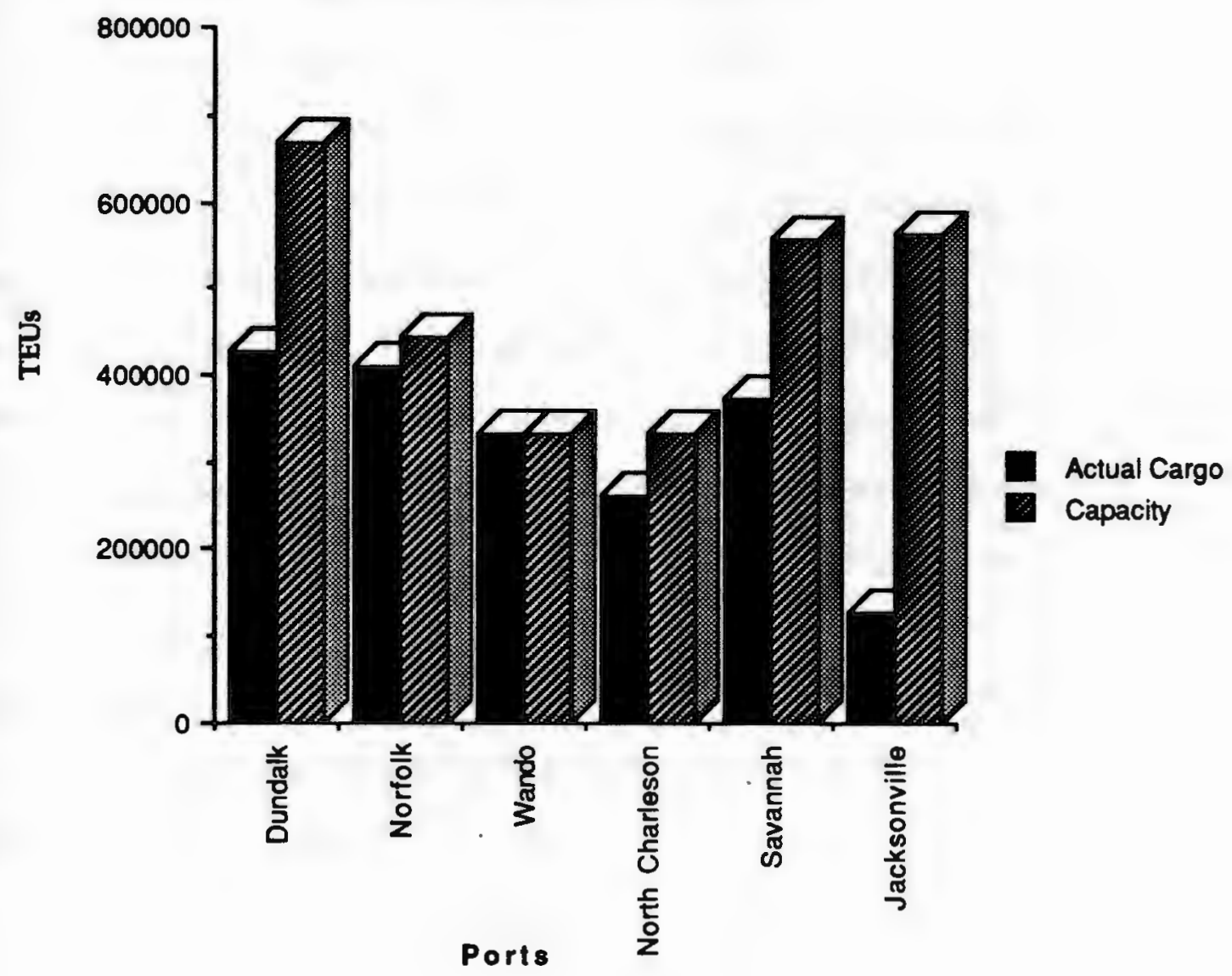

Source: Individual ports and author's calculations 


\section{CHAPTER FOUR}

\section{CONCLUSIONS}

The analysis presented in the previous chapter demonstrates that there is excess capacity among container facilities in the ports of Baltimore, Norfolk, Charleston, Savannah and Jacksonville. Although it is not as high as it was previously thought to be ( 49 percent) by the author, overcapacity is growing as ports commit more of their resources to container facility development. Despite the proven 33 percent overall excess capacity at the ports studied, every port has planned or already begun development for the expansion of their container facilities. The large ports along the mid-Atlantic range have enough excess capacity to handle most of the cargo moving through smaller ports such as Brunswick and Newport News which were not included in this study. Future expansion represents significant public expenditure and coastal land development which may not be necessary. It is the responsibility of public policy-makers to eliminate public waste and prevent unnecessary costs to society. This thesis has shown that there may be a need for better management on a regional level. Specifically, it calls for:

1) mandating capacity and productivity assessment by individual ports to justify development plans;

2) disseminating information about individual port development requirements;

3) sharing capacity information; 
4) improving federal participation involving capacity assessments, and management and operations guidance from a stronger MARAD; and,

5) Including technical information on development needs for federal, state and local permit reviews.

The previous suggestions will facilitate information exchange among regulators and ports so that port development requirements can be included in permit decision-making. The availability of information will help ports assess their needs effectively and can help prevent unneeded development and overcapacity-a potential advantage to the port as well as to society.

Welch (1991) states that only two ports in the entire South Atlantic are achieving successful economic returns. On both business and public levels, this is unacceptable. Economic inefficiencies coupled with a certain degree of overcapacity in public ports are obvious costs to society.

The federal government has chosen to let the individual state ports govern their own development. In the competitive port industry, state rather than federal control has resulted in disjointed, inefficient management and unnecessary facility duplication. The only strong regulatory role of the federal government is dredging regulation. While the protection and preservation of the environment remains important, so does the economic success of existing port facilities.

If the federal government took a more active role in the development of port facilities, it could promote development of financially and operationally efficient container facilities. Federal policy is necessary at this time. There are too many inefficient ports. There is too much excess. 
Ports often publish their yearly revenue and the multiplier impacts of the port facility. This is misleading to the port community and to the nation. Revenues do not indicate the actual success of the port because all costs are not included. Including multiplier effects as a port benefit vastly overstates the total economic benefit of a port. Ports in the U.S. should all have positive rates of return. The indication, however according to Welch (1991), is that they do not. Changes must be made in management that will correct this inefficiency. It is imperative that public ports serve the public as valuable resources

The costs of overcapacity discussed in this thesis are inefficiencies in public expenditure and coastal land use. This social problem is of national concern on many levels. Too often, ports see environmental regulations to development as hampering their ability to compete. Occasionally, this view may be warranted. However, protection of the environment is a national concern in addition to the economic benefits of international trade. There is also an inherent dichotomy between economic development and environmental protection. This does not need to be the case. National interests do include economic prosperity and environmental preservation at the same time. There can be a balance between the two that results in a positive net-benefit to society. It is more attainable if the federal government accommodates all of its interests with regard to port development and environmental protection. In this respect, more efficient management needs to be fostered by the federal government. By merely concerning itself with environmental regulations against development, the federal government only hampers a port's ability to compete and operate effectively. This is not efficient government. 
Ports attempt to utilize their land and funds efficiently. But, the competitive nature of state-operated ports does not encourage intra-state planning and cooperation. Because there is neither cooperation nor communication among ports, duplication of facility occurs. This results in a slow, continuous process of overdevelopment. Negative net-returns can be the eventual result.

In some countries, large "load-centers" are federally controlled to prevent overdevelopment and facility duplication. Considering the greater size of the U.S. and availability of its resources, more medium-sized efficient ports may provide for a better distribution of economic port benefits and better utilization of coastal lands. What is recommended is a policy of continued state control, but with greater federal involvement. While there is often conflict between state and federal goal-setting, cooperation is possible, as exhibited by the National Coastal Zone Management Program.

To eliminate inevitable conflicts between state and federal governments, the federal role in port management should be to provide guidance through a better funded Maritime Administration-through standard mandatory capacity analysis and assistance in productivity management. The experts in MARAD can work directly with individual ports, replacing other inexperienced government organizations.

This thesis has attempted to show the value of a capacity assessment to determine port requirements. On a broad scale, capacity results may be less accurate; but, individually, in-house analysis can be very precise when all the facts about operations are available. If all individual port capacity assessments were to be made available, unnecessary development may be avoided. Knowledge of port requirements and the trade role of individual ports along a range can result in better planning and management decision-making, and 
more efficient use of port land and public funds. The resources saved can then be used to improve the productivity of existing facilities and to build financial success in each port.

It has been suggested that U.S. ports operate inefficiently, with overcapacity and financial waste. This thesis has proved the existence of overcapacity in container facilities along the mid-Atlantic port range from Baltimore to Jacksonville. While capacity assessment does not provide a panacea for all the problems in the port industry, it does present port managers with the information necessary to make better decisions that can focus public port resources on existing facilities and away from waste. 


\section{BIBLIOGRAPHY}

Abernathy, Walter. "But What About The View?: ports face land use and environmental limits ahead." Pacific Shipper, February 24, Sec. II (1986) 46-52.

Ashar, Asaf. " Productivity and Capacity of Container Terminals (II)." WWS,Vol. 48, No. 7, Dec/Jan. (1986) : 93-95.

Boschken, Herman L.. Strategic Design and Organizational Change: Pacific Rim Seaports in Transition, University of Alabama Press, Tuscaloosa (1988).

Boschken, Herman L. " Strategic Planning of Seaport Development in a Global Economy: Observations of an Executive Port Director." Coastal Zone Management Joumal, Vol. 14, No. 3 (1986) : 193-215.

Boschken, Herman L.. Port Authorities as Public Enterprises, University of Southern California Sea Grant Program, Los Angeles (1982).

Brinson, J. Ron. " The U.S. Port System: Expanding Capabilities, and Major Challenges," Sea Power. February (1980) : 29-33.

Container News. " Racines Terminal's High Speed Cranes," Vol.23, November (1988) : 30 .

Container News. "World Ports Survey 1986," Vol. 21, No. 5, May: 28-73 (1986).

Containerisation International. "Box Moves Finally Accelerate as Ports Total Top 47 Million TEU in 1983," Vol. 18, No. 7, July (1984) : 62-65.

Containerisation International. "Overcapacity Still Plagues TransAtlantic Trades," Vol. 21, No. 10, October (1987) : 75.

Containerization International Yearbook. Containerisation International, London, England (1989).

Containerization Intermational. " Charleston: The Model American Seaport," Vol. 22, No. 11, November (1988) : 60-61.

Cowey, Ann Breen. " The Urban Coast from a National Perspective," Coastal Zone Management Joumal, Vol. 6, No. 2-3 (1979) : 135-162. 
Dowd, T.J. and T.M. Leschine. " Container Terminal Productivity: A

Perspective," Maritime Policy and Management. Vol. 17, No. 2 (1990): 107-112.

Frankel, Ernst. Studies on the Future of Atlantic Ports. No. MIT-72-18.

Cambridge, Massachusetts: Massachusetts Institute of Technology, Sea Grant Profect Office (1970).

Gilman, S. " Technological Change and Strategic Re-development in Cityports, University of Southampton, Department of Geography, International Seminar, Waterfront Re-Development and the Cityport Economy. November (1987).

Hagan, Ann H. " Diminishing Availability of Land," WWS/World Wide Shipping, June (1990) : 41-43.

Hall, Vernon E. "2020 Plan: The San Pedro Bay Ports", Proceedings of the 1st International Coastal Ocean Space Utilization Symposium, May 810, 1989, New York (1990) : 169-173.

Hayuth, Yehuda. Intermodality: concept and practice, Lloyd's of London Press (1987).

Hershman, Marc J. ed. Urban Ports and Harbor Management, Taylor and Francis, New York (1988).

Hershman, Marc., et. al. Under New Management, Port Growth and Emerging Coastal Management Programs, Seattle,University of Washington Press, Washington Sea Grant (1978).

Hikkila, Eric. " Structuring a National System of Ports," Portus (1990).

Hirshleifer, Jack. Price Theory and Applications, Prentice-Hall, Inc., Englewood Cliffs, New Jersey, fourth ed. (1988).

Holmes, Beatrice Hort. " Federal Participation in Land Use

Decisionmaking at the Water's Edge- Floodplains and Wetlands." Natural Resources Lawyer. Vol. 18, No. 2. (1980) : 351-410.

Jourmal of Commerce. Friday, June 3 (1990) : 9c.

Kalo, Joseph J. Coastal and Ocean Law, The John Marshal Publishing Company, Houston, Texas (1990).

Kelly Daniel F. " The Port Director's Dilemma: Competition Spurs Overcapacity," International Trade \&Export, October (1987) : 30-34. 
Kenyon, J. B. " Land Use Admixture in the built-up Urban Waterfront:

Extent and Implications." Economic Geography, Vol. 44 (1968) : 152-77 .

Kula, Thomas. Load Center Feeder Service Potential, Masters Thesis, University of Rhode Island (1984).

Lambert, Mark. " Port Results for 1985 show an end to boom in Box Traffic,"Containerisation International, Vol. 20, No. 7, July (1986) : 5557.

lloyds Shipping Economist. " U.S. East Coast Ports: offensive and defensive strategies," Vol. 10, January (1988) : 6-11.

Marcus, Henry S., James E. Short, John C. Kuypers, and Paul O. Roberts. Federal Port Policy in the United States. The Massachusetts Institute of Technology Press (1976).

Maritime Administration. United States Department of Commerce, National Port Assessment 1980/1996, Washington, D.C.: U.S. Government Printing Office, June (1980).

Maritime Administration. United States Department of Commerce, United States Port Development Expenditure Survey, Washington, D.C.: U.S. Government Printing Office, January (1980).

Marti, Bruce E. " Shift-Share Analysis and Port Geography: A New England Example," Maritime Policy and Management, Vol. 9, No. 4 (1982) : 241-250.

Morril, Stephen. " Desert Shield/Desert Storm Boosts southeast Ports' Economies", WWS/World Wide Shipper, July/August (1990) : 52.

National Academy of Sciences, National Research Council. Port Development in the United States. Prepared by the Panel on Future Port Requirements on the United States, Maritime Transportation Research Board, Commission on Sociotechnical Systems, Washington, D.C (1976).

National Research Council. Improving Productivity in U.S. Marine Container Terminals, National Academy Press, Washington, D.C (1986).

National Research Council. Public Involvement in Maritime Facility Development, Washington, D.C.: National Academy of Sciences (1979). 
New Jersey Council for Social Studies and the Bureau of Governmental Research. "Authorities as a governmental Technique," Rutgers University. March 26 (1953).

Northern California Ports and Terminals Bureau. " NORCAL: Trade Outlook of the Northern California Ports." (1975).

Payne, Stanley. "The Legal Right of a Port to Cargo in the age of Containerization: Going, going...not quite gone." Transportation Law Journal, Vol. 14, No. 2 (1986) : 249-325.

Pisani, John. Port Development in the United States(Status, Issues and Outlook), U.S. Department of Transportation Washington, D.C. (1989)

Port Development International. Container Crane Supplement '87, July/August (1987) : i-xx.

Port of Baltimore.Annual Report, Port of Baltimore (1989).

Port of Charleston Issue. Brandon's Shipper and Forwarder, Vol. 112, No. 24, June 16 (1986) : 9-16.

Port of Savannah Issue. Brandon's Shipper and Forwarder Vol. 112, No. 39, October 27 (1986) : 7-16.

Schenker, Eric and Harry C. Brockel. Port Planning and Development as related to Problems of U.S. Ports and the U.S. Coastal Environment, Cornell Maritime Press Inc., Cambridge, Maryland (1974).

Schrier, Elliot. " An Analysis of Container Capacity in the Inbound Pacific Trades, Brandon's Shipper and Forwarder, Vol. 112, No. 32, Aug.11 (1986) : 6 .

Simms, George C. " Are There Too Many Ports?" Portus, April, Canada Ports Corporation, Ottawa (1989).

Talley, Wayne K. " Optimum Throughput and Performance Evaluation of Marine Terminals," Maritime Policy and Management, Vol. 15, No. 4 (1988) :327-331.

Talley, Wayne K. " The Role of U.S. Ocean Ports in Promoting an Efficient Ocean Transportation System," Maritime Policy and Management, Vol. 15, No. 2 (1988) : 147-155.

" U.S. East and Gulf Ports." Asian Shipper, April, No. 88 (1986) : 27-44. 
Varaprasad, N. " Optimum Port Capacity and Operating Policies: a Simulation Study," Trans-Port Policy and Decision-Making, Vol. 3, No. 4 (1985) : 297-312.

Welch, Don W. "Contemporary Challenges to U.S. Public Port Management," WWS/World Wide Shipping, May (1990) : 52-57.

Yochum, Gilbert R., and Vinod B. Agarwal. The Economic Impact and Rate of Return of Virginia's Ports on the Commonwealth. College of Business and Public Administration, Old Dominion University (1988): 43 and 45. 